\title{
REVIEW
}

\section{Diagnostic and therapeutic approach to infectious diseases in solid organ transplant recipients}

\author{
Jean-François Timsit ${ }^{1,2^{*}}$, Romain Sonneville ${ }^{3,4}$, Andre C. Kaliil ${ }^{5}$, Matteo Bassetti ${ }^{6}$, Ricard Ferrer ${ }^{7}$, \\ Samir Jaber ${ }^{8}$, Fanny Lanternier ${ }^{9,10}$, Charles-Edouard Luyt ${ }^{11,12}$, Flavia Machado ${ }^{13}$, Malgorzata Mikulska ${ }^{14}$, \\ Laurent Papazian ${ }^{15}$, Fréderic Pène ${ }^{16,17}$, Garyphalia Poulakou ${ }^{18}$, Claudio Viscoli ${ }^{14}$, Michel Wolff ${ }^{19}$, Lara Zafrani $^{20}$ \\ and Christian Van Delden ${ }^{21}$
}

(c) 2019 Springer-Verlag GmbH Germany, part of Springer Nature

\begin{abstract}
Purpose: Prognosis of solid organ transplant (SOT) recipients has improved, mainly because of better prevention of rejection by immunosuppressive therapies. However, SOT recipients are highly susceptible to conventional and opportunistic infections, which represent a major cause of morbidity, graft dysfunction and mortality.

Methods: Narrative review.

Results: We cover the current epidemiology and main aspects of infections in SOT recipients including risk factors such as postoperative risks and specific risks for different transplant recipients, key points on anti-infective prophylaxis as well as diagnostic and therapeutic approaches. We provide an up-to-date guide for management of the main syndromes that can be encountered in SOT recipients including acute respiratory failure, sepsis or septic shock, and central nervous system infections as well as bacterial infections with multidrug-resistant strains, invasive fungal diseases, viral infections and less common pathogens that may impact this patient population.
\end{abstract}

Conclusion: We provide state-of the art review of available knowledge of critically ill SOT patients with infections.

Keywords: Sepsis, Immunocompromized, Solid organ recipient, Septic shock, Outcome

\section{Introduction}

Each year, approximately 90,000 transplants are performed worldwide, more than two-thirds in the USA and Europe, and the number of solid organ transplant (SOT) recipients living with a functioning graft has been growing. In the USA, 19,849, 8000, 3200 and 2449 renal, liver, heart and lung transplants were performed in 2017, respectively (http://www.unos.org/donation). Over the

*Correspondence: Jean-francois.timsit@aphp.fr

${ }^{1}$ Medical and Infectious Diseases ICU (MI2), APHP Bichat University Hospital, 75018 Paris, France

Full author information is available at the end of the article past decades, improvement of graft survival has mainly been attributed to better prevention of acute rejection by immunosuppression therapies. However, these immunocompromised patients are more susceptible to infections caused by both conventional and opportunistic infections, and infection is now the first cause of death of SOT recipients. The diagnosis of infection is often delayed by torpid initial clinical presentation with a secondary and abrupt occurrence of shock and organ dysfunctions. In the present article, we review the main diagnostic and therapeutic approaches to SOT recipients with infections admitted to the ICU. 


\section{Epidemiology of severe infections in organ transplant recipients}

Infections represent the main cause of death within 1 year after heart or lung transplantation, accounting for $32 \%$ and $35 \%$ of deaths during this period, respectively. Although with a lesser incidence, infections remain an important cause of death and/or loss of graft survival [1]. The susceptibility of SOT recipients to infections relies on multiple factors including pre-transplant characteristics (i.e., prior immune and non-immune conditions and critical illness), type of transplanted organ, intraoperative characteristics (i.e., prolonged duration of cold ischemia, longer duration of transplant procedure and requirement of blood transfusions) and post-transplant factors (i.e., degree of immunosuppression, prophylaxis and cytomegalovirus infection). Of note, the development of cytomegalovirus infection by itself causes immunosuppression, which further increases the risk of severe bacterial and fungal infections [2,3]. A timeline of common post-transplant infections has been proposed [4, 5]: severe infections may occur during three classical periods, namely the post-surgical phase $(<4$ weeks $)$, the period of maximum immunosuppression (1-12 months) and thereafter (>12 months) [5] (Fig. 1). Increasing indications of organ transplantation are observed with higher age limits and sicker patients [6], accentuating the incidence of post-transplant infectious complications. Pretransplant critical illness is invariably associated with a higher risk of infection [7] and correlates with the risk of postoperative morbidity and mortality [8]. Approximately

\section{Take-home messages}

Organ transplantation increases worldwide. The main risk of complication is related to infections, whereas graft rejection risk is now stable. Infectious risk is mainly related to postoperative and nosocomial infections at the early phase. In the intermediate and late phases, opportunistic infections may occur and should be diagnosed early. During the late phase, community-acquired infection risk is common and higher for organ transplant recipients than for immunocompetent patients. Prophylaxis and adapted early preemptive therapy are key to improving global prognosis. ICU admission of infected patients is mainly due to acute respiratory failure, coma and shock. Early diagnostic tests should be oriented toward clinical symptoms, medical history and antimicrobial prophylaxis. Early treatment is key to improve prognosis in solid organ transplant recipients with severe infections

$6 \%$ of lung transplant recipients in the USA are supported by a ventilator or extracorporeal membrane oxygenation (ECMO) at the time of transplant [9]. Recent studies in heart transplant recipients suggest that $25 \%$ of patients had ECMO support at the time of transplant $[7,10]$.

During the first month after transplantation, infections result from surgical complications, donor-derived infections, preexisting recipient infections and nosocomial infections [11]. The risk is higher for heart, lung and liver transplant recipients compared with kidney transplants. Risk factors that predispose to early postoperative infections (Fig. 2) can be categorized as being present before transplant (recipient or donor) and those secondary to intraoperative or post-transplantation factors [12].

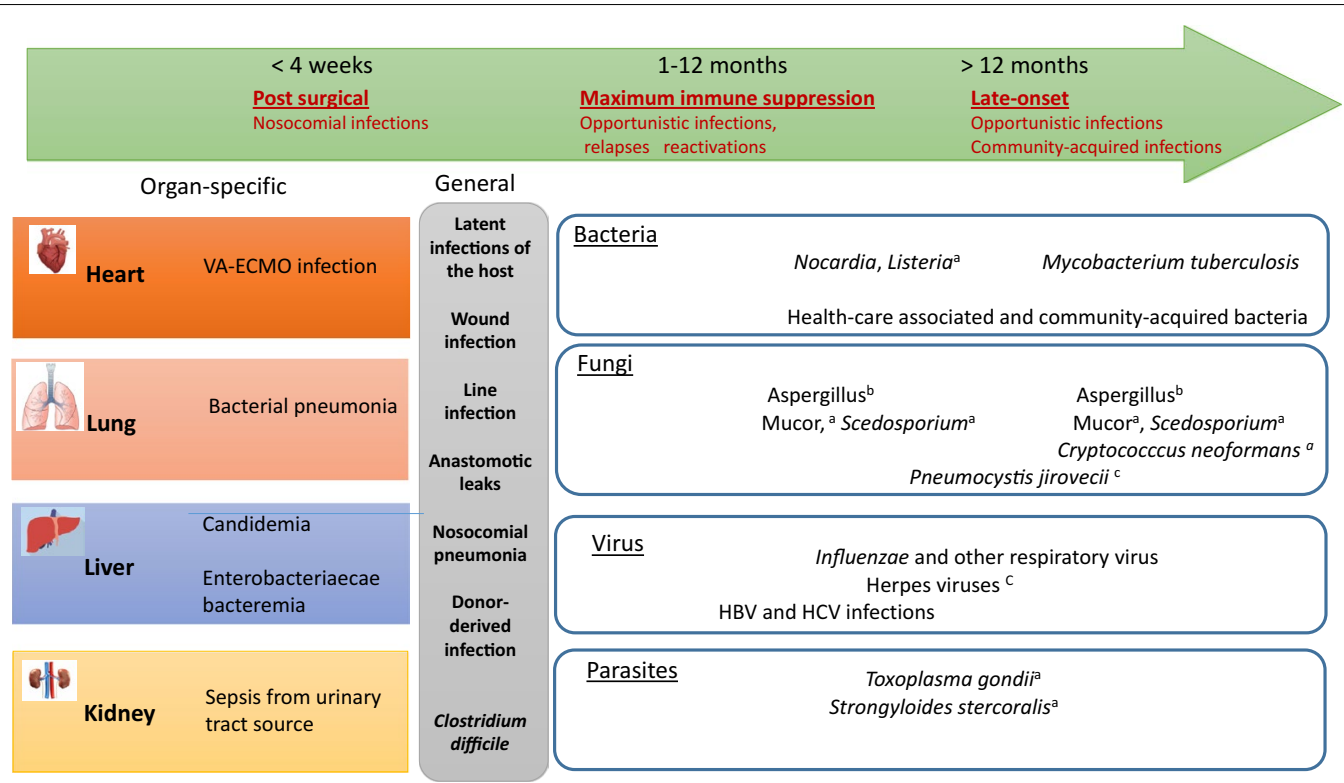

Fig. 1 Timeline of the main severe infections after solid-organ transplantation. a Low incidence in SOT recipients; $\mathbf{b}$ highest incidence in lung transplant recipients; $\mathbf{c}$ mostly in patients without effective prophylaxis 


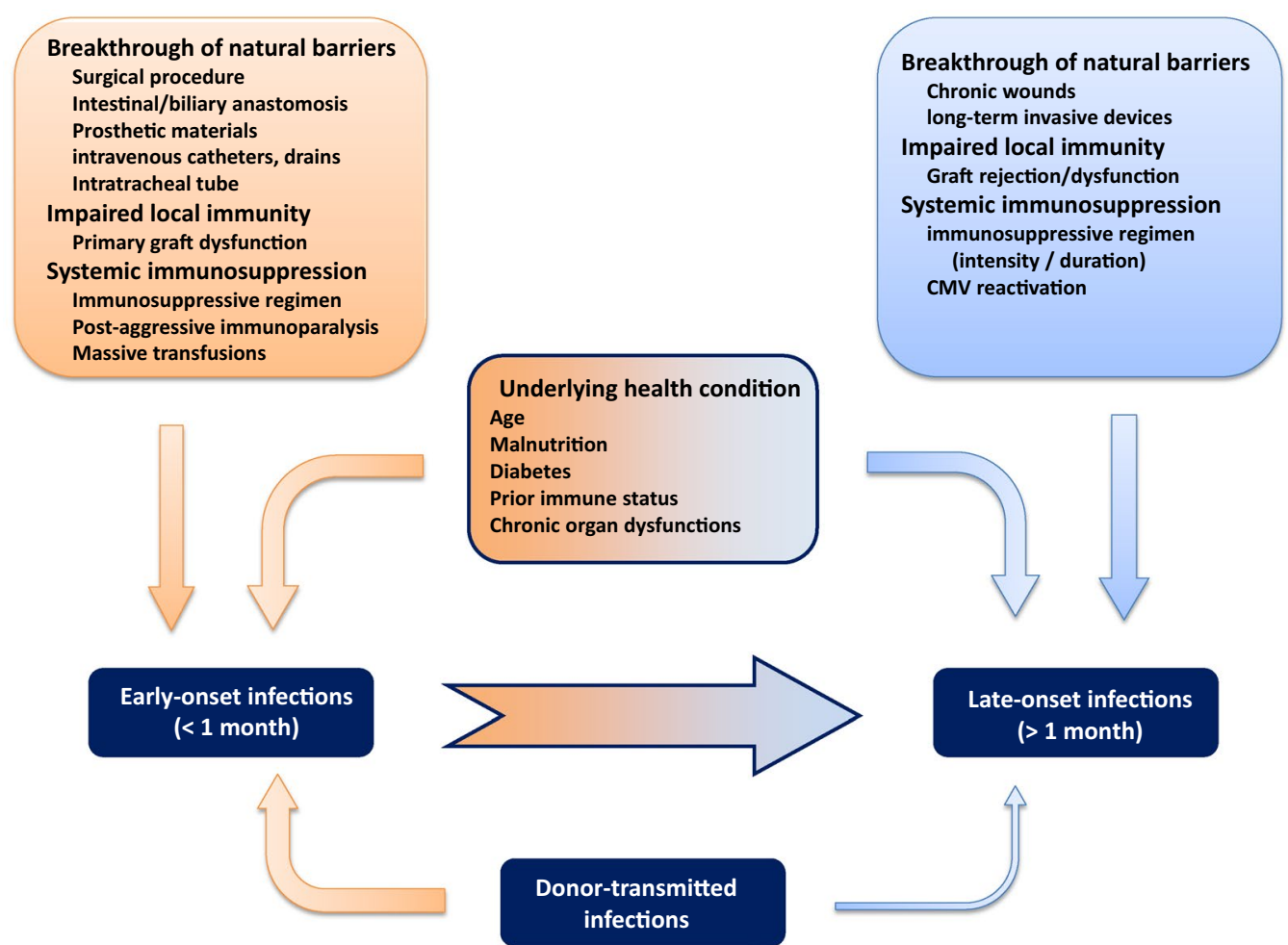

Fig. 2 Baseline and acquired determinants of infections in SOT recipients. The recipient's prior health condition accounts for the risk of infections throughout the post-transplantation period. Early-onset infections are related to acquired defense alterations including breakthrough of natural barriers and immune suppression. Late-onset infections are mostly related to the intensity of the immunosuppressive regimen

Kidney allograft recipient characteristics associated with a higher risk of early postoperative infection include ureteral anastomotic leaks, contaminated perfusate, urinary catheters, ureteral stents and central venous catheters. Risk factors for infection at later time points include vesico-ureteral reflux, polycystic kidney disease, increased albumin excretion and deceased donor kidneys [13]. The most common site of infection is the urinary tract, and abdominal ultrasound is always indicated to identify possible foci for source control such as perinephric abscess, fungal ball or ureteral obstruction. In liver recipients, risk factors are directly related to the allograft anatomy. Pre-transplant conditions such as primary sclerosing cholangitis predispose recipients to postoperative biliary stenosis and anastomotic strictures, both associated with higher risk of bacterial sepsis [14]. The higher the pre-transplant level of bilirubin, the higher the risk of severe infections after transplant. Of note, the Roux-en-Y choledochojejunostomy is more frequently associated with biliary infections than the duct-to-duct biliary anastomosis for biliary drainage [15]. Clinical presentation includes acute cholangitis, intra-hepatic or abdominal abscesses, secondary peritonitis and bacteremia. The recurrence of hepatic abscess is suggestive of hepatic artery thrombosis, while the development of peritonitis suggests the presence of biliary leakage. In case of hepatitis $\mathrm{C}$ virus (HCV)-positive patients undergoing liver transplantation with detectable $\mathrm{HCV}$ viremia, infection of the allograft within hours of organ transplantation as well as recurrent infection is almost universal. HCV recurrence may be prevented by completed direct-acting antiviral therapy before liver transplantation [16] or, if not feasible, started on the day of transplantation until 4 weeks postoperatively [17]. In heart recipients, the pre-transplant need for ventricularassist devices, intra-balloon pumps, pacemakers and defibrillators is associated with higher risk of post-transplant mediastinitis, aortic suture infections and dehiscence [18]. In lung recipients, the denervation of the allograft is accompanied by a reduced cough reflex and impaired mucociliary clearance, which in turn increase the predisposition to severe pneumonias and sepsis.

Expected donor-derived infections might be caused by CMV [19], Epstein-Barr virus (EBV) and Toxoplasma spp., so preventive strategies are entertained according to the serologic status of the donor and recipient. Unexpected donor-derived infections include Mycobacterium tuberculosis, hepatitis B and C viruses [20], West Nile 
virus, Histoplasma spp. or human immunodeficiency virus [21]. Finally, donor-derived bacterial and/or fungal infections might also be observed [22]. Contamination of the preservation fluid is a rare but sometimes dreadful complication, especially when Candida sp. is involved [23].

Infections occurring later (1-12 months after transplant) are mainly due to reactivation of latent infections (cytomegalovirus/CMV, herpes simplex virus/HSV, varicella-zoster virus/VZV) and opportunistic pathogens (Aspergillus spp., Pneumocystis jirovecii, Cryptococcus neoformans, Toxoplasma gondii, Legionella pneumophila, Mycobacteria spp., Nocardia spp.).

Infections occurring after 12 months include community-acquired and healthcare-associated infections. Clostridium difficile infection is common following transplantation and should be considered in case of diarrhea [24].

Overall, 30-60\% of all SOT recipients develop sepsis at any time during the post-transplant period [25-27], mostly nosocomial in the first 2 months, and opportunistic and community-acquired thereafter. SOT recipients are three times more frequently admitted from emergency departments [28] and have 18 times higher risk of developing nosocomial infections [29] compared with non-transplant patients. The fact that SOT recipients are significantly more prone to nosocomial infections makes them also more susceptible to multidrug-resistant (MDR) bacterial infections, including gram-negative bacilli and methicillin-resistant Staphylococcus aureus [30]. Acute respiratory failure is the most frequent symptom and is observed in up to $50 \%$ of kidney transplant patients requiring ICU admission [31].
In a recent multicenter international study, SOT recipients accounted for $9 \%$ of immunocompromised patients admitted to the ICU for acute hypoxemic respiratory failure [32]. Respiratory infection is the most frequent complication after SOT, following a relatively predictable pattern depending on the time elapsed since transplantation $[5,33,34]$.

\section{Assessing the risk of infections in solid organ transplant recipients}

Pretransplant lymphopenia may predict the incidence of infection up to 2 years after liver transplantation [35, 36]. In the post-transplant period, kinetics of lymphocyte subsets are inaccurate predictors of opportunistic infections [37-39]. An immunologic score, the so-called immunoscore, can be computed from immunologic markers, including immunoglobulins, complement levels and lymphocyte subsets readily available in clinical practice. In heart transplant recipients, a high immunoscore was independently associated with an increased risk of severe infection within the next 3 months [37]. However, the receiver-operator characteristic curve $(0.80)$ for predicting infection suggests that the risk of infection not only relies on quantitative depletion of immune effectors but also on qualitative cell dysfunctions (Fig. 3).

Measurement of intracellular ATP levels reflects the metabolic activity of $\mathrm{T}$ cells and therefore accounts for a surrogate marker of $\mathrm{T}$ cell fitness. Accordingly, low and high ATP levels have been associated with increased risks of infection and rejection, respectively. However, studies that assessed the performance of ATP levels in identifying infection and rejection risks have been conflicting [40]. Very recently, a global immunity assay was

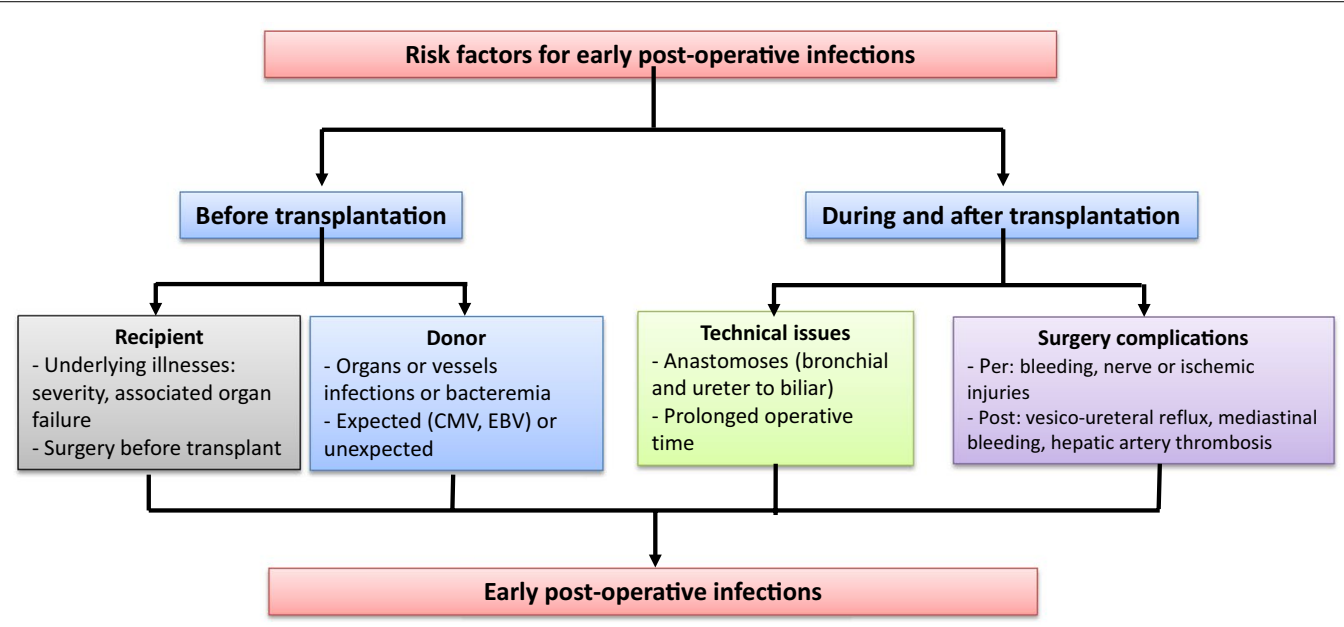

Fig. 3 Risk factors for early postoperative infections in SOT recipients. Risk factors that predispose to early postoperative infections in recipients of organ transplantation can be categorized as being present before transplant (recipient or donor) and those secondary to intraoperative or posttransplantation factors 
developed to assess the IFN $\mathrm{I}_{\gamma}$ production in whole blood following stimulation of $\mathrm{T}$ cells with anti-CD3 antibody and of innate cells with the TLR7 ligand R848. The

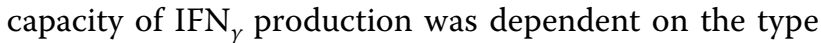
of immunosuppressive regimen and thus was markedly impaired in patients under anti-thymocyte globulin and higher dosing of prednisone and mycophenolate. A low IFN ${ }_{\gamma}$ production capacity at 1, 3 and 6 months was associated with the development of further bacterial and opportunistic infections [41]. Further works are needed to characterize individual immune function and to assess the relative risk of specific etiologies of infections.

\section{Key points for anti-infective prophylaxis}

Prophylaxis during the first month following SOT is mainly directed against nosocomial infections related to the donor and surgery. Antibacterial prophylaxis should always take into account the type of transplant as well as colonization of both donor and recipient and should be given for the shortest time possible (Table 1). In case of recipient colonization by an extended spectrum $\beta$-lactamase (ESBL) producing Enterobacteriaceae, the prophylaxis should include an antibiotic active against these organisms, sparing carbapenems, if possible [42]. In case of colonization with carbapenemase-producing Enterobacteriaceae (CPE), the risk-benefit ratio may not favor prophylaxis with CPE-active antibiotics, except in centers with a high incidence of surgical site infections [42]. Cystic fibrosis lung transplant recipients frequently harbor MDR bacteria prior to transplantation. These patients should receive early post-transplant prophylaxis based on both donor and recipient bronchial cultures [43].

Prophylaxis has significantly reduced the incidence of opportunistic infections (Table 2) [44, 45]. For CMV prevention, the choice between universal prophylaxis versus preemptive therapy depends on the type of transplant as well as on donor-recipient serology status [46]. After 6 months, in parallel with a progressive reduction in immunosuppression, prophylaxis against opportunistic pathogens can be gradually discontinued. However, prophylaxis should be reinitiated in case of increased immunosuppression to treat rejection episodes.

Of note, severe hypogammaglobulinemia after SOT is associated with CMV, fungal and respiratory infections and with a decrease in the 1-year survival [47, 48]. However, increasing IgG levels to $\geq 400 \mathrm{mg} / \mathrm{dl}$ did not translate into better patient or graft survival [47].

\section{Acute respiratory failure (ARF)}

Respiratory complications after solid organ transplantation (SOT) are frequent, including infectious and non-infectious complications, i.e., lung edema, primary graft dysfunction (PGD), pulmonary hemorrhage or acute respiratory distress syndrome (ARDS) [33]. As the etiology of ARF in SOT recipients is highly variable, appropriate treatment requires timely and accurate diagnosis, the latter being complex because of the effects of immunosuppression, which obscure the signs and symptoms of infection [49]. In some cases, an invasive diagnostic approach is needed to differentiate between infectious and non-infectious causes of ARF (Table 2). Infection may be suspected by laboratory and radiographic abnormalities, but the chest X-ray could be normal in as many as $10 \%$ of immunocompromised patients with pneumonia, and evidence may only be present on computed tomography. Lung ultrasound is evolving as an accurate bedside diagnostic tool in critically ill SOT recipients [50-52]. Flexible bronchoscopy is a useful tool in the evaluation of ARF in SOT recipients, and it should be considered early. Microbiologic sampling in bronchoalveolar lavage (BAL), biomarker determination in BAL and plasma (procalcitonin, $\beta$-D-glucan and galactomannan) and molecular diagnostic tests are useful to drive the antimicrobial therapy in these patients $[49,51]$. Additionally, lung biopsy will be needed to discard graft rejection in lung transplant recipients with overlapping clinical features. Respiratory infections heavily impact the final outcome of SOT, increasing morbidity, including chronic lung allograft dysfunction, and mortality. The emergence of MDR pathogens in post-transplantation infections puts SOT recipients at increased risk of threatening difficult-to-treat complications [50,51].

\section{Septic shock}

Some specific features should be taken into account when managing SOT patients with septic shock.

In case of high suspicion of sepsis, onset of broad antibiotic and antifungal therapy is an emergency taking into account specific risk factors for MDR bacteria [53], until identification of the infectious agent and antifungal [54] or antibacterial [55] de-escalation. Non-invasive assays aiming to screen for infections could help to start earlier appropriate antimicrobial therapy [19]. The usefulness of the multiplex panel or next-generation sequencing technologies may be of interest, but these techniques deserve to be validated in SOT recipients. Efforts should be made to find the cause of infection [32], with particular attention to differential diagnoses or a surgical cause that would require surgical revisions [56]. The differential diagnosis of non-infectious complications (i.e., acute allograft rejection or drug-induced toxicity) is complex and may mimic sepsis features $[57,58]$. 

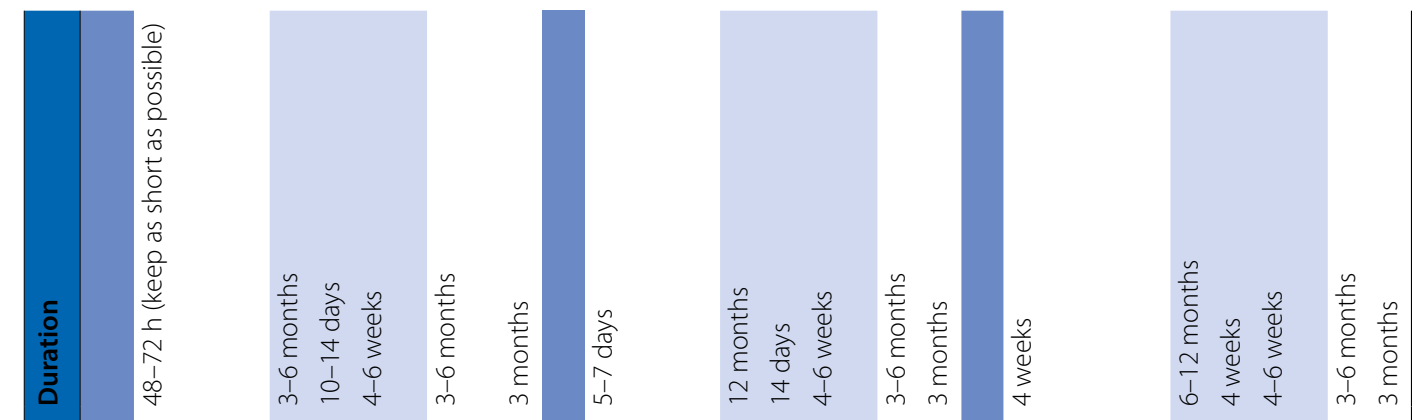

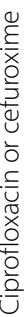
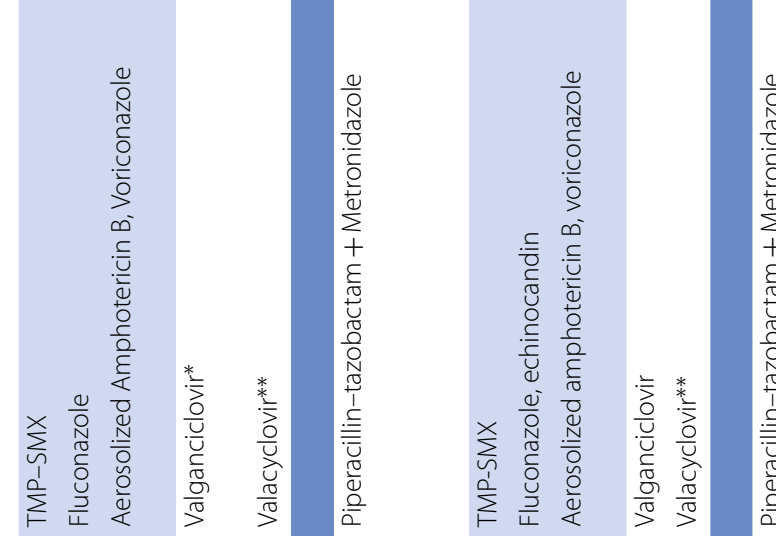

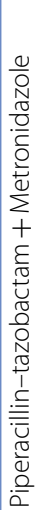
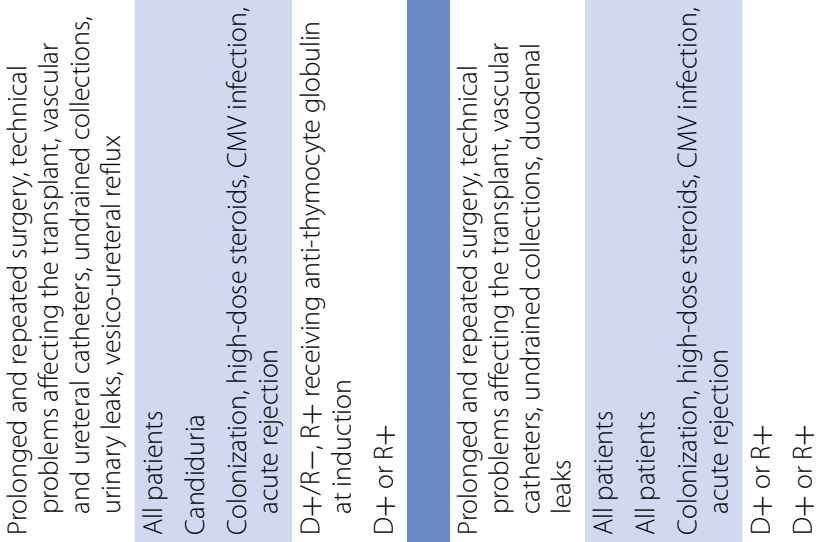

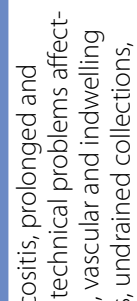

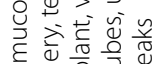

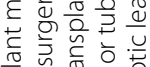

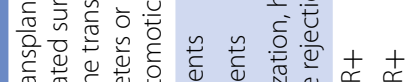

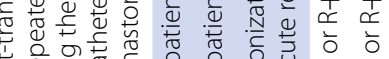

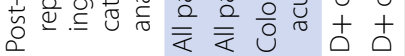
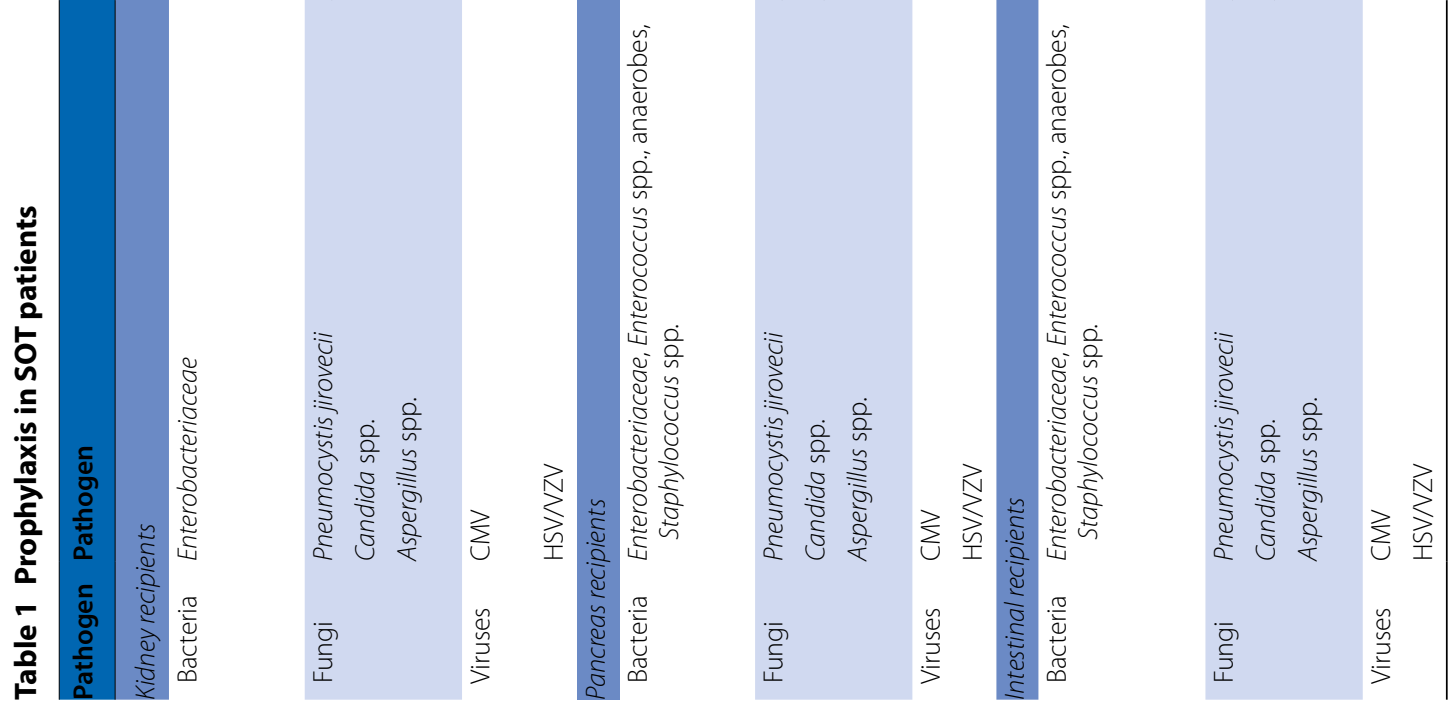


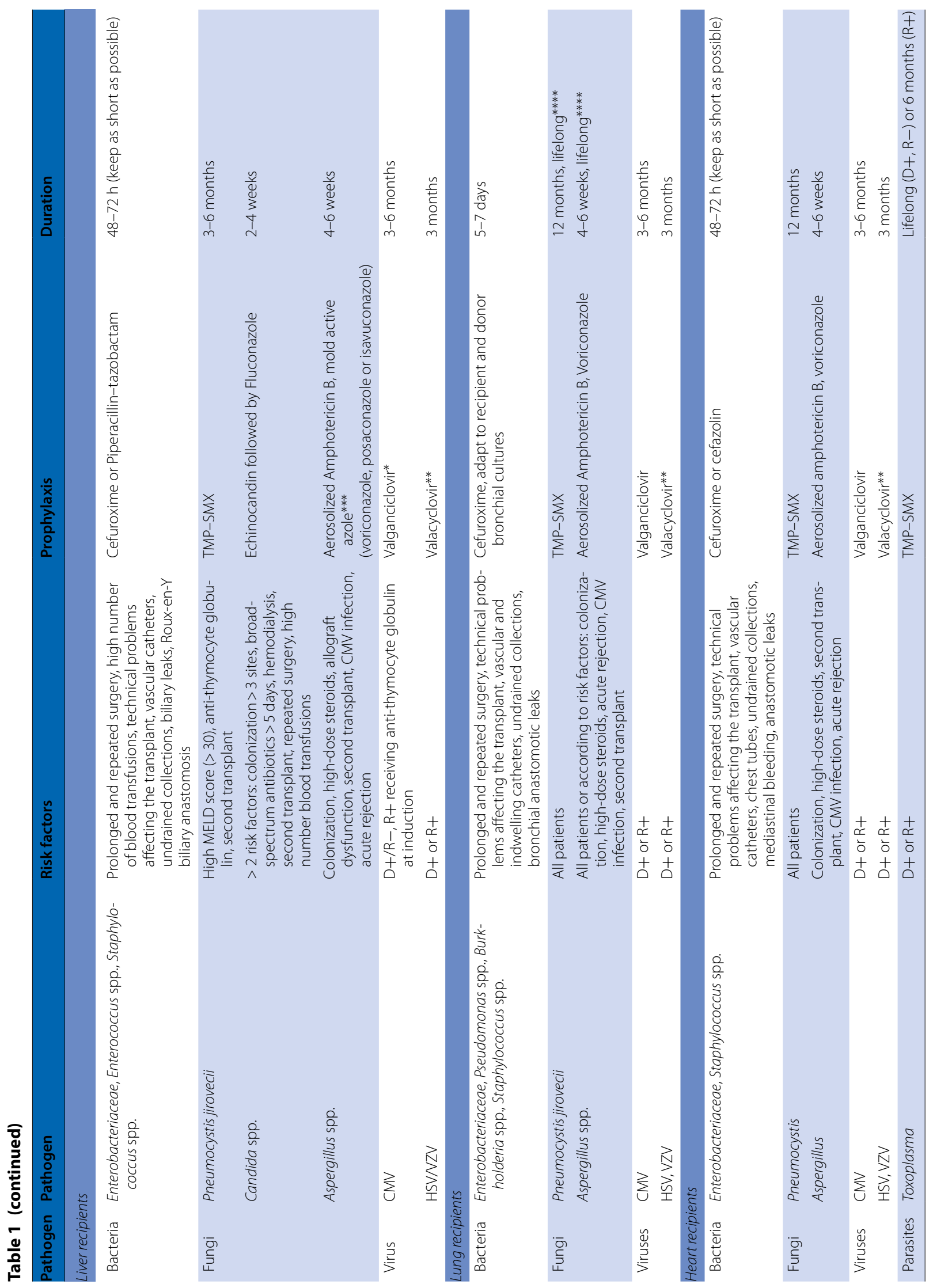


Drug interactions between immunosuppressive agents (e.g., calcineurin or mammalian target of rapamycin inhibitors) and antibiotics (e.g., rifampicin, macrolides) or azole antifungal treatment should be systematically considered [59] (Fig. 4). Any delay of adequate empiric antibiotic therapy is detrimental, as it is associated with increased mortality in the SOT population [60, 61].

There is no consensus on the management of immunosuppressive drugs in critically ill patients with sepsis [62]. Some authors suggest withdrawing immunosuppressive drugs to accelerate sepsis recovery [63]. However, the benefit of this strategy has not been proven yet and may expose the patient to the risk of allograft rejection [64]. Hydrocortisone should be considered in all septic SOT recipients on corticosteroids before ICU admission to avoid adrenal insufficiency [65]. Concerning the choice of fluids, crystalloids should be used as first-line, while colloids such as hydroxyethyl starches, when used in deceased organ donors, have been associated with delayed graft function in kidney transplant recipients [66]. Use of vasopressors should also follow current guidelines, where norepinephrine is proposed as the drug of choice [67]. Inotropic drugs should be considered in those who fail to respond to adequate fluids and vasopressors and also have myocardial depression [67]. However, the response to vasopressors may be modified in SOT recipients. For example, some authors have suggested that sympathetic denervation in kidney transplants may increase the effect of norepinephrine on renal vascular resistance [68]. The response to inotropic drugs may also be decreased in heart transplant recipients [68].

\section{CNS infections in SOT recipients}

In patients receiving chronic immunosuppressive therapy after solid organ transplantation (SOT), central nervous system (CNS) opportunistic infections typically occur within 6-12 months following transplantation [69, 70]. A general diagnostic approach to neurologic complications of SOT is proposed elsewhere [71]. Main diagnostic studies for SOT patients with a suspicion of CNS infection are presented in Table 3.

Fungi are a frequent cause of cerebral abscesses among SOT recipients, e.g., resulting from infection by Aspergillus, Mucorales, Scedosporium or Fusarium species [72, 73]. Aspergillus sp. may also be responsible for ischemic and hemorrhagic brain lesions [74]. Voriconazole is the standard treatment for CNS aspergillosis but requires therapeutic drug monitoring to optimize therapy and avoid toxicity (optimal trough concentrations of 2-5 $\mu \mathrm{g}$ per $\mathrm{ml}$ in serum). Voriconazole has a $50 \%$ penetration coefficient in the CNS, and measurement of CSF concentrations is not necessary in routine. For patients experiencing severe adverse effects under voriconazole as 
Table 2 Non-invasive and invasive diagnostic tools for acute respiratory failure in SOT recipients

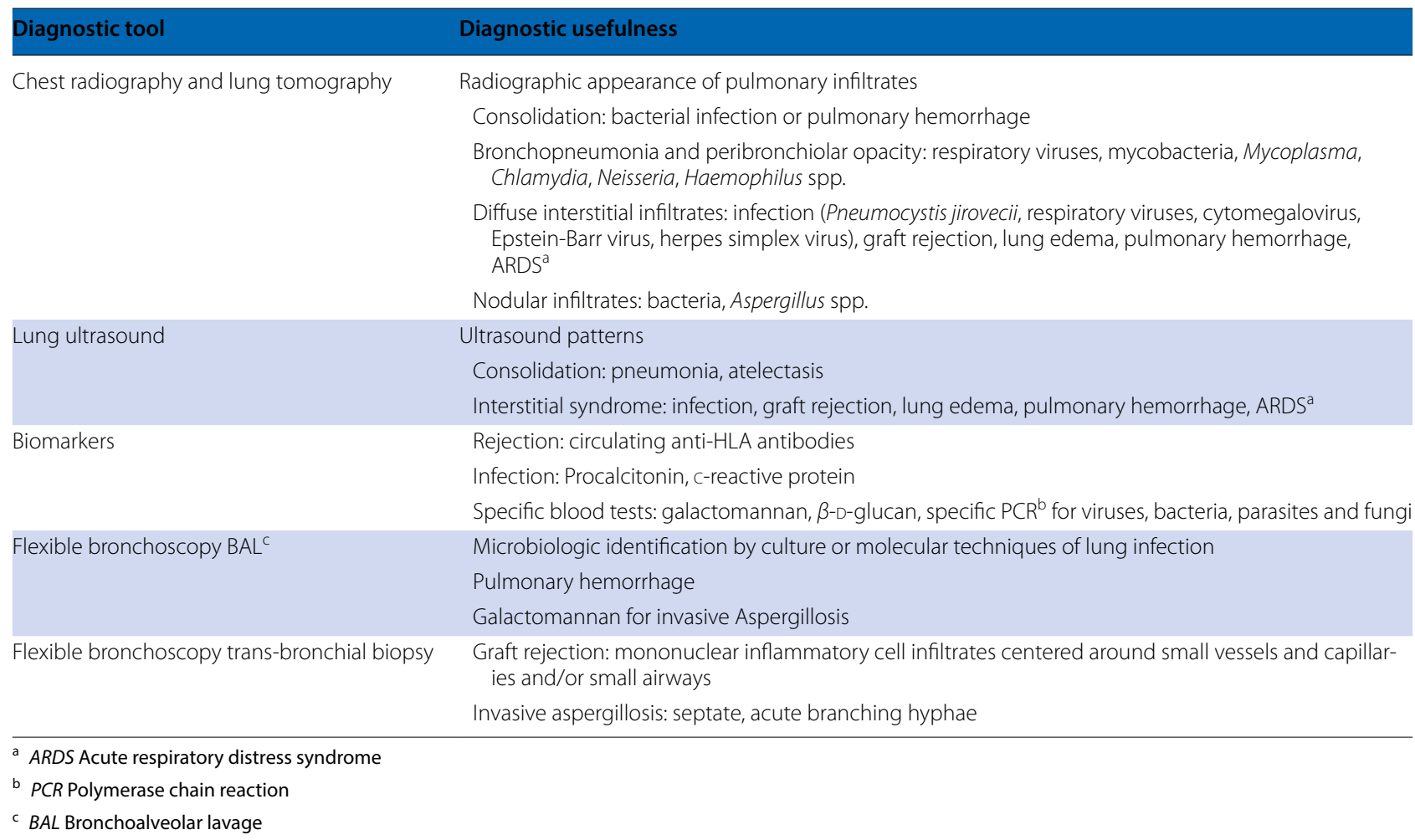

primary therapy, liposomal amphotericin B is an alternative. Monitoring of the therapeutic response in patients with altered mental status should be based on serial CT or MR scans with an initial interval of 1 to 2 weeks. Neurosurgery should be consulted for any patient presenting with a suspicion of CNS aspergillosis or other mold infection. In the absence of extra-CNS involvement (i.e., a pulmonary or sinus source of infection), a definitive diagnosis requires brain biopsy, with prompt inspection of the specimen. In patients presenting with space-occupying lesions or hydrocephalus, surgical decompression [with debulking or stereotactic drainage of lesion(s)] and insertion of an extraventricular drainage catheter should be discussed, respectively.

Other common microbial isolates in brain abscesses of SOT recipients include Nocardia species, Toxoplasma gondii and Mycobacterium tuberculosis. Nocardiosis is more frequent after thoracic transplantation and prolonged ICU stay in case of an intense immunosuppressive regimen (high calcineurin inhibitor trough concentration, high-dose steroids) and/or use of tacrolimus [75]. More than $40 \%$ of patients have a disseminated infection, including lung and cutaneous involvement. CNS involvement occurs in one-third of patients and can be asymptomatic, suggesting that systematic brain imaging is mandatory at diagnosis. Cotrimoxazole is the drug of choice, but other drugs such as linezolid, carbapenems and amikacin have been proposed [76]. The most common presentation of Toxoplasma gondii infection in SOT recipients is primary infection with (multi)-organ disease (i.e., retinochoroiditis, pneumonia, myocardial involvement) with or without neurologic features, i.e., meningitis and/or (multi)-focal brain lesions [77]. A negative serostatus prior to transplantation represents the only risk factor associated with the disease [78]. In most patients, the diagnosis will be made by means of specific (CSF) PCR. Myocardial involvement is associated with poor outcome.

The incidence of bacterial meningitis is seven-fold higher compared with the general population, and causative pathogens include Streptococcus pneumoniae and gram-negative bacilli [79]. Cryptococcosis is a rare and severe complication of SOT, especially in lung transplant recipients, with CNS involvement being observed in $50 \%$ of cases [80]. Tuberculous meningitis has also been reported in SOT [81], but its exact incidence is unknown.

HSV and VZV are common viruses causing encephalitis in immunocompromised individuals, although clinical manifestations may be atypical (i.e., absence of fever, absence of CSF pleocytosis, atypical MRI patterns) and thus challenging to recognize [82]. In the setting of SOT, donor-transmitted infections can result in rare causes of 
Table 3 Main diagnostic studies of SOT patients with a suspicion of CNS infections

\begin{tabular}{|c|c|c|c|c|c|c|}
\hline Pathogen & Clinical picture & CSF findings & Brain imaging & CSF samples & Blood samples & Other samples \\
\hline \multicolumn{7}{|l|}{ Bacteria } \\
\hline $\begin{array}{l}\text { Streptococcus } \\
\text { pneumoniae } \\
\text { Neisseria menin- } \\
\text { gitidis } \\
\text { Gram-negative } \\
\text { bacilli } \\
\text { Listeria monocy- } \\
\text { togenes }\end{array}$ & $\begin{array}{l}\text { Acute onset } \\
\text { Altered mental } \\
\text { status } \pm \text { neck stiff- } \\
\text { ness } \pm \text { fever }\end{array}$ & $\begin{array}{l}\text { Pleocytosis } \\
\quad(100-10,000 / \\
\left.\text { mm }^{3}\right) \\
\text { Neutrophils } \\
\text { High Pt; Low Glu }\end{array}$ & $\begin{array}{l}\text { Normal or } \\
\text { infarction } \\
\text { Diffuse edema }\end{array}$ & $\begin{array}{l}\text { Direct examination } \\
\text { and culture } \\
( \pm 16 \text { s RNA }) \\
\text { mPCR }\end{array}$ & Blood cultures & $\begin{array}{l}\text { Depending on clini- } \\
\text { cal presentation }\end{array}$ \\
\hline $\begin{array}{l}\text { Mycobacterium } \\
\text { tuberculosis }\end{array}$ & $\begin{array}{l}\text { Subacute onset } \\
\text { Altered mental sta- } \\
\text { tus } \pm \text { fever } \pm \text { focal } \\
\text { signs }\end{array}$ & $\begin{array}{l}\text { Pleocytosis } \\
\left(100-1000 / \mathrm{mm}^{3}\right) \\
\text { Lymphocytes } \\
\text { High Pt; Low Glu }\end{array}$ & $\begin{array}{l}\text { Arachnoiditis } \\
\text { Infarction } \\
\text { Hydrocephalus } \\
\text { Tuberculoma }\end{array}$ & $\begin{array}{l}\text { Direct and culture } \\
\text { (3-5 ml, repeat CSF } \\
\text { analysis) } \\
\text { PCR for Mycobacte- } \\
\text { rium tuberculosis } \\
\text { complex }\end{array}$ & QuantiFERON-TB & $\begin{array}{l}\text { Pulmonary samples } \\
\text { Brain biopsy }\end{array}$ \\
\hline Nocardia spp. & $\begin{array}{l}\text { Subacute } \\
\text { onset } \pm \text { fever } \\
\text { Altered mental } \\
\text { status } \pm \text { focal } \\
\text { signs } \pm \text { extra neuro- } \\
\text { logic involvement }\end{array}$ & Variable & Abscess(es) & $\begin{array}{l}\text { CSF direct } \\
\text { examination and } \\
\text { culture }( \pm 16 \mathrm{~s} \\
\text { RNA) }\end{array}$ & Blood cultures & $\begin{array}{l}\text { Skin biopsy (cultures) } \\
\text { Respiratory samples } \\
\text { Brain biopsy }\end{array}$ \\
\hline \multicolumn{7}{|l|}{ Viruses } \\
\hline $\begin{array}{l}\text { Herpes simplex } \\
\text { virus }\end{array}$ & $\begin{array}{l}\text { Acute onset of } \\
\text { altered mental } \\
\text { status } \pm \text { focal } \\
\text { signs, } \pm \text { fever, } \pm \text { sei- } \\
\text { zures }\end{array}$ & $\begin{array}{l}\text { Pleocytosis (>5/ } \\
\text { mm }^{3} \text { ) } \\
\text { Lymphocytes } \\
\text { High Pt; Normal } \\
\text { Glu }\end{array}$ & Temporal lesion(s) & $\begin{array}{l}\text { PCR HSV1 and } \\
\text { HSV2 }\end{array}$ & $\begin{array}{l}\text { PCR HSV1 and } \\
\text { HSV2 }\end{array}$ & - \\
\hline $\begin{array}{l}\text { Varicella zoster } \\
\text { virus }\end{array}$ & $\begin{array}{l}\text { Acute onset of } \\
\text { altered mental } \\
\text { status } \pm \text { focal } \\
\text { signs, } \pm \text { fever, } \pm \text { sei- } \\
\text { zures }\end{array}$ & $\begin{array}{l}\text { Pleocytosis (>5/ } \\
\text { mm }^{3} \text { ) } \\
\text { Lymphocytes } \\
\text { High Pt; Normal } \\
\text { Glu }\end{array}$ & Ischemic lesions & PCR VZV & PCR VZV & Skin biopsy (PCR) \\
\hline Cytomegalovirus & $\begin{array}{l}\text { Subacute onset of } \\
\text { altered mental } \\
\text { status } \pm \text { fever }\end{array}$ & $\begin{array}{l}\text { Pleocytosis (> 5/ } \\
\text { mm }^{3} \text { ) } \\
\text { Lymphocytes } \\
\text { High Pt; Normal } \\
\text { Glu }\end{array}$ & Ventriculitis & PCR CMV & PCR CMV & - \\
\hline JC virus & $\begin{array}{l}\text { Subacute onset of } \\
\text { altered mental } \\
\text { status } \pm \text { focal } \\
\text { signs } \pm \text { seizures }\end{array}$ & $\begin{array}{l}\text { Absence of pleo- } \\
\text { cytosis }\end{array}$ & $\begin{array}{l}\text { Multifocal } \\
\text { white matter } \\
\text { lesions }\end{array}$ & PCR JC virus & - & - \\
\hline HHV6 & $\begin{array}{l}\text { Sub-acute onset of } \\
\text { altered mental } \\
\text { status } \\
\text { Working-memory } \\
\text { deficit }\end{array}$ & $\begin{array}{l}\text { Pleocytosis (> 5/ } \\
\text { mm }^{3} \text { ) } \\
\text { Lymphocytes } \\
\text { High Pt; Normal } \\
\text { Glu }\end{array}$ & Limbic lesions & PCR HHV6 & - & - \\
\hline Epstein-Barr virus & Focal signs & - & Focal lesion & PCR EBV & - & $\begin{array}{l}\text { Brain biopsy if focal } \\
\text { mass (look for } \\
\text { lymphoma) }\end{array}$ \\
\hline \multicolumn{7}{|l|}{ Parasites and fungi } \\
\hline $\begin{array}{l}\text { Aspergillus and } \\
\text { other molds }\end{array}$ & $\begin{array}{l}\text { Focal deficits } \pm \text { extra } \\
\text { neurologic involve- } \\
\text { ment }\end{array}$ & Variable & $\begin{array}{l}\text { Cerebral infarcts } \\
\text { Hemorrhage } \\
\text { Mycotic aneurysm } \\
\text { Abscess++ }\end{array}$ & $\begin{array}{l}\text { Direct examina- } \\
\text { tion and fungal } \\
\text { cultures } \\
\text { Galactomannan } \\
\text { 1-3- } \beta \text {-D-glucan }\end{array}$ & $\begin{array}{l}\text { Galactomannan } \\
1-3-\beta \text {-D-glucan }\end{array}$ & $\begin{array}{l}\text { Pulmonary samples } \\
\text { Skin biopsy } \\
\text { Brain biopsy }\end{array}$ \\
\hline $\begin{array}{l}\text { Toxoplasma } \\
\text { gondii }\end{array}$ & $\begin{array}{l}\text { Altered mental status } \\
\text { Focal } \\
\text { signs } \pm \text { fever } \pm \text { sei- } \\
\text { zure }\end{array}$ & Variable & Abscess(es) & $\begin{array}{l}\text { PCR Toxoplasma } \\
\text { gondii }\end{array}$ & PCR & $\begin{array}{l}\text { Pulmonary sam- } \\
\text { ples + brain biopsy }\end{array}$ \\
\hline
\end{tabular}


Table 3 (continued)

\begin{tabular}{|c|c|c|c|c|c|c|}
\hline Pathogen & Clinical picture & CSF findings & Brain imaging & CSF samples & Blood samples & Other samples \\
\hline $\begin{array}{l}\text { Cryptococcus } \\
\text { neoformans }\end{array}$ & $\begin{array}{l}\text { Sub-acute onset } \\
\text { Altered mental } \\
\text { status } \pm \text { fever }\end{array}$ & $\begin{array}{l}\text { Pleocytosis } \\
\quad\left(100-1000 / \mathrm{mm}^{3}\right) \\
\text { Lymphocytes } \\
\text { High Pt; low Glu }\end{array}$ & $\begin{array}{l}\text { Normal } \\
\text { Cryptococcoma }\end{array}$ & $\begin{array}{l}\text { India ink stain and } \\
\text { culture } \\
\text { Cryptococcal } \\
\text { antigen } \\
\text { PCR }\end{array}$ & $\begin{array}{l}\text { Blood cultures } \\
\text { Cryptococcal } \\
\text { antigen }\end{array}$ & Pulmonary samples \\
\hline
\end{tabular}

Pulmonary samples should be considered in patients with respiratory symptoms and/or lung involvement on imaging

Brain biopsy should be considered in patients presenting with focal lesion(s) with edema and mass effect in the absence of extra-CNS involvement and negative CSF analysis or contraindication to lumbar puncture because of risk of herniation

Skin biopsy should be considered in patients with skin lesion(s)

CSF cerebrospinal fluid, $P C R$ polymerase chain reaction, $R N A$ ribonucleic acid; Glu CSF glucose level, $P t$ CSF protein level

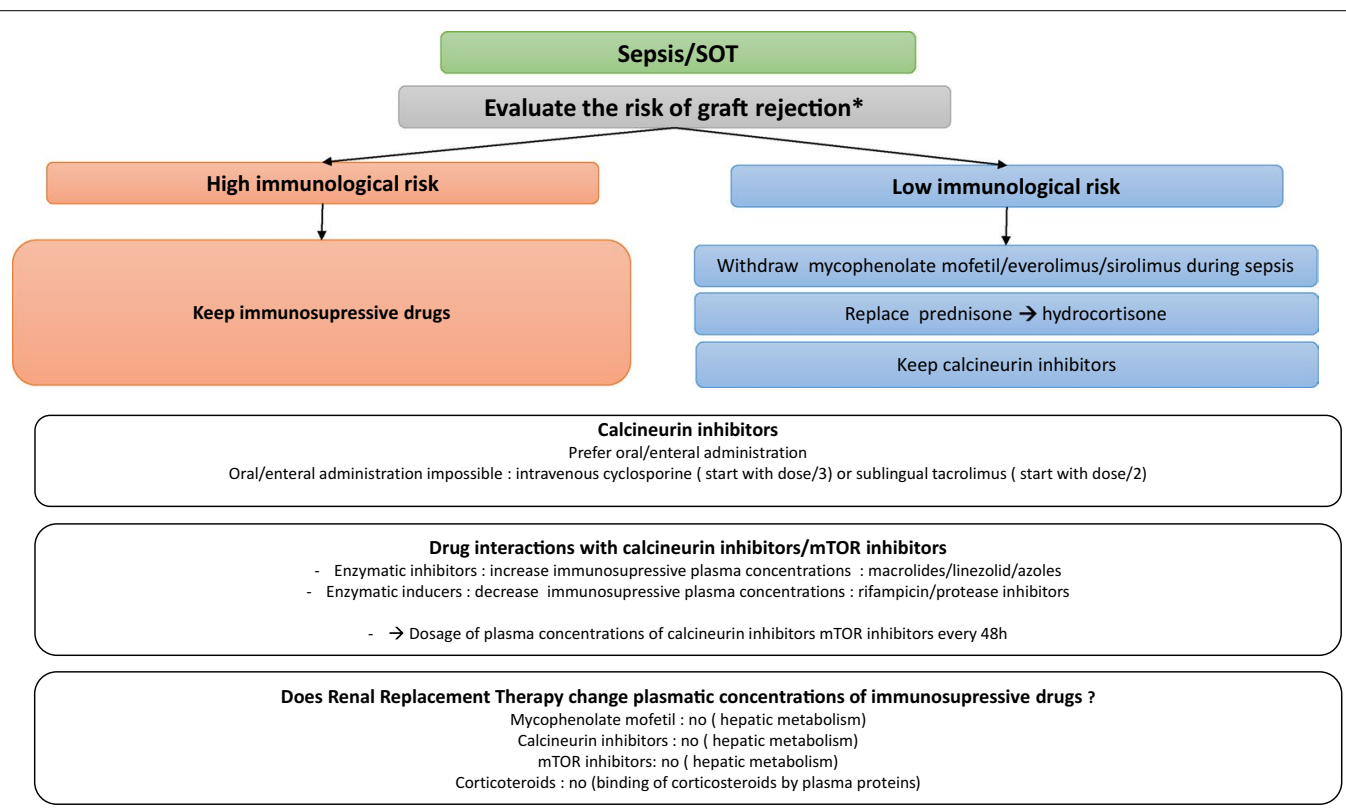

Fig. 4 Adaptation of the immunosuppressive drugs at the initial phase of sepsis: practical issues. *Immunologic risk assessment: deceased donor, number of human leukocyte antigen (HLA) mismatches, donor-specific antibodies (DSA), organ-specific differences (heart-lung $>$ kidney $>$ liver).

Withdrawal of IS drugs should be discussed in close collaboration with transplant physicians

encephalitis, including infection by human herpes virus-6 and BK virus. Progressive multifocal leukoencephalopathy (PML) has been reported in SOT recipients, with a higher case fatality rate and a higher incidence than reported in human immunodeficiency virus patients or multiple sclerosis patients treated with natalizumab [83]. Future studies using multiplex CSF PCR and next-generation sequencing techniques may allow a faster diagnosis and help identify new pathogens, respectively.

\section{Impact of multidrug-resistant (MDR) bacteria on the risk of severe infections in SOT recipients}

SOT recipients represent a particular setting of patients at risk of developing MDR infections, as they are frequently and broadly exposed to multiple antibiotic courses, invasive procedures, immunosuppressive treatments and have repeated contacts with healthcare structures-all of them highly recognized and proven risk factors for MDR bacterial infections [84]. No specific recommendations about prevention and treatment in this setting are currently available.

Transplant recipients are exposed to risk developing hospital- and healthcare-associated infections, especially in the early post-transplant period. SOT recipients are typically infected by non-fermenting gram-negative bacilli (i.e., Pseudomonas aeruginosa, Burkholderia spp., Stenotrophomonas spp. or carbapenem-resistant Acinetobacter baumannii), extended-spectrum $\beta$-lactamases (ESBL) and carbapenem-resistant enterobacteriaceae (CRE), especially carbapenem-resistant Klebsiella 
pneumoniae (CRKP) as well as gram-positive organisms, such as vancomycin-resistant enterococci (VRE) and methicillin-resistant Staphylococcus aureus (MRSA).

Colonization with MDR organisms, acquired prior to transplantation, may include bacteria that could be resistant to agents used regularly for surgical prophylaxis. On this basis, some important points for management of SOT recipients should be routinely assessed: (1) resistance profiles of all isolates (colonizers and pathogens) should be obtained; (2) donor colonization should not constitute a contraindication to transplantation; however, donation should be avoided from donors with CRE bacteremic infections as well as kidney grafts from donors with CRE urinary tract infections and lung grafts from donors with CRE lung infections; (3) recipient colonization is associated with an increased risk of infection, but it is not considered a contraindication to SOT; (4) different surgical prophylaxis regimens are not recommended for patients colonized with carbapenem-resistant pathogens; (5) detection of carriers, contact isolation precautions, hand hygiene compliance and antibiotic control policies are important measures to prevent MDR infections [42].

Some other important considerations should be reported: colonized lung transplant recipients could benefit from prophylactic inhaled antibiotics, especially for Acinetobacter baumannii and Pseudomonas aeruginosa infection; colonized SOT recipients should receive an empirical treatment that includes active antibiotics, and directed therapy should be adjusted according to susceptibility and disease severity. Finally, no data are currently available about potential benefit of intestinal decolonization [85].

Therapeutic rules are similar in SOT recipients and other ICU patients [86]. Three points should therefore be pointed out: (1) SOT recipients have a higher risk of infections due to MDR bacterias [87]. (2) Pharmacologic interactions and multiple drug exposures may expose patients to an increased risk of inadequate dosing and toxicities. (3) The shortening of treatment duration is not demonstrated in SOT recipients and should be discussed on an individual basis $[88,89]$.

\section{Invasive fungal infections}

Invasive fungal disease (IFD) is associated with morbidity, reduced graft survival and mortality in SOT recipients. The risk and type of IFD mainly depend on the type of transplant. Invasive candidiasis is the most frequent IFD, occurring mostly in the first year after transplant. Invasive aspergillosis (IA) represents $25 \%$ (except for lung transplant, 59\%) and cryptococcosis 7\% of IFD in SOT recipients [90]. Mold infections occur after the first year especially in lung transplants, but earlier onset infections have been reported in liver transplant recipients presenting more frequently with disseminated disease (55\%) [91]. Preventive measures and diagnostic strategies for IFD therefore depend on the type of organ transplanted and associated risk factors and are presented in Table 4.

Donor-derived infections occur mostly within 30 days post-transplant. Candida vascular infections due to preservation fluid contamination are mostly reported for kidney and liver transplants [23, 92]. Graft-transmitted cryptococcosis, coccidioidomycosis and aspergillosis have also been reported [93, 94]. SOT recipients treated for IFD are also at risk to develop immune reconstitution syndrome (IRS) after immunosuppression tapering. It is classically reported in cryptococcosis [95] but also in histoplasmosis. IRS is reported in $15 \%$ of SOT patients developing cryptococcosis. Risk factors include CNS disease and discontinuation of calcineurin inhibitors [96]. IRS is associated with more graft rejection. IRS treatment mainly includes corticosteroids and, in rare cases, TNFalpha inhibitors [97].

Invasive candidiasis represents $50-60 \%$ IFD in SOT recipients. They are mostly bloodstream infections (44\%), followed by intra-abdominal (14\%), and occur mostly in liver (41\%) and kidney (35\%) transplant. Mortality is higher in liver transplant [98]. Diagnosis relies on blood cultures and treatment with echinocandins or fluconazole in non-severe, non-azole pre-exposed patients.

Aspergillosis incidence is high in lung and heart transplant recipients (8.3 and $7.1 \%$ in the Swiss cohort) [90]. Diagnosis relies on CT scans [that show images of angioinvasive invasive pulmonary aspergillosis (IPA) in only half of patients], respiratory specimen assays including direct examination (49\%), culture (70\%) and galactomannan assay $(\mathrm{GM})$ positivity in blood $(35 \%)$ or BAL (39\%). Serum beta-D-glucan had a poor positive predictive value of $27 \%$ in a cohort of SOT recipients (mostly lung) for IFI [99]. Two studies showed the importance of voriconazole for IA treatment in both kidney and liver transplant recipients with demonstrated reduced mortality $[100,101]$.

Pneumocystis pneumonia mostly occurs 2 years posttransplant because of universal prophylaxis during the first year. It is associated with age, total lymphocyte count and CMV infection [102-104]. Clinical presentation may be severe with a $40 \%$ rate of ICU admission [103]. Use of corticosteroids in SOT recipients with pneumocystis pneumonia is a matter of debate.

\section{Viral infections}

Viral infections in SOT recipients may be divided into opportunistic infections and common respiratory viral infections. Opportunistic viral infections are mainly due to herpesviridae, CMV being the most frequently 


$$
1
$$


encountered. Typically, CMV infection (defined as evidence of CMV replication regardless of symptoms [46]) occurs in the first 3 months after transplantation in patients without prevention, but may be delayed in patients with prophylaxis. CMV disease (defined as evidence of CMV infection with attributable symptoms [46]) may present as isolated fever, cytopenia or organ involvement (colitis or enteritis, pneumonia, hepatitis or less frequently myocarditis, pancreatitis or central nervous system involvement) and is usually preceded by virus reactivation [5]. Moreover, CMV disease is associated with an increased rate of bacterial and fungal infections (due to virus-induced immunosuppression $[3,4]$ ) and post-transplant lymphoproliferative disorders [105]. Curative treatment of CMV disease or CMV organ involvement includes the use of intravenous ganciclovir, duration depending on the clinical picture and kinetics of viral load, but for at least 2-3 weeks, and reduction of immunosuppression [46]. The rate of CMV disease has decreased with preventive measures (prophylaxis and preemptive treatment). Prophylaxis, routinely recommended for all transplants from CMV IgG-positive donors $(\mathrm{D}+)$ to CMV IgG-negative recipients $(\mathrm{R}-)$, consists of valganciclovir or ganciclovir administration during a given period (generally $3-12$ months, depending on the organ grafted) [46]. Preemptive treatment is based on viral load surveillance (CMV-DNA testing) and treatment when the virus load exceeds a specific threshold. However, thresholds for triggering antiviral therapy are not standardized, but range between 1500 and $4000 \mathrm{IU} /$ $\mathrm{ml}$ [1]. This should be adapted according to organ and individual risk. CMV IgG-negative recipients $(\mathrm{R}-)$ of organs from negative donors (D-) should not receive prophylaxis or be monitored for CMV reactivation, but tested in case of clinical suspicion [46]. The best strategies (prophylaxis or preemptive treatment) depending on donor/recipient serostatus and transplant types are summarized in Table 1 [46]. Other herpesviridae (HSV, EBV) are less frequent or lead to less severe disease.

SOT is, like other immunosuppressive conditions, a risk factor for severe influenza disease [106]. A recent multicenter study showed that influenza pneumonia was frequent in SOT recipients [107], but its incidence might be decreased, as well as the need for ICU admission, by influenza vaccination and early antiviral therapy [107]. An influenza vaccination strategy should be adapted in SOT recipients: compared with single simple dose, high dose [108] or double dose regimens (given 5 weeks apart) [109] were associated with increased antibody response. Non-influenza respiratory viruses (rhinoviruses, coronaviruses, human metapneumovirus, respiratory syncytial virus and adenoviruses) may also be responsible for severe respiratory infection, especially in lung transplant recipients [110, 111], leading in some cases to chronic lung allograft dysfunction [112]. Moreover, it seems that viral-bacterial and/or fungal co-infection is more common than in immunocompetent individuals and that viral shedding is longer in SOT recipients than in immunocompetent patients [111]. Although antiviral treatments are limited and the timing of their administration not clearly defined, all SOT recipients with suspected respiratory infection should be sampled (nasopharyngeal sample or deep lung if mechanically ventilated) to test for these viruses (including influenza) by PCR. Treatment is mainly supportive, but also includes specific antiviral treatment, if available, and reduction of immunosuppression [113]. Empiric oseltamivir should be given in all respiratory infections as early as possible during the flu period in SOT recipients and continued or withdrawn according to PCR results. In case of severe influenza, lung transplant recipients and other particularly severely immunosuppressed SOT recipients (i.e., having recently received anti-rejection therapy and/or anti-thymocytes globulins) should receive a combination therapy including oral oseltamivir and baloxavir. There is no evidence that a double dose of oseltamivir is superior to a single dose; therefore, $75 \mathrm{mg}$ twice daily is recommended for all patients. If oral therapy is impossible, intravenous peramivir is an option. Inhaled zanamivir has not been evaluated in patients with severe influenza and in SOT patients (in particular lung transplant recipients) and could therefore not be recommended for routine use. Intravenous zanamivir may be another alternative, in particular in case of oseltamivir-resistant influenza infections, but is only available for compassionate use. Duration of therapy should depend on therapeutic response and respiratory viral loads measured by PCR: oseltamivir can be stopped after 5 days if there is clinical improvement and virus is no longer detected, but should be continued for 10 days in all other cases, in particular for severe influenza.

\section{Uncommon pathogens that should be known}

Non-tuberculous mycobacteria (NTM) are ubiquitous in the environment and stand out as the most important uncommon pathogens in SOT recipients. Among them, Mycobacterium avium and M. intracellulare [commonly referred as Mycobacterium avium complex (MAC)] are the most common NTM species causing disease in SOT recipients [114]. Less commonly encountered NTMs include the slow-growing $M$. kansasii, M. haemophi$l u m$ and $M$. marinum and the rapid-growing $M$. fortuitum, M. chelonae and M. abscessus. The lung is affected in $>50 \%$ of cases, with heart and lung recipients being more vulnerable (range from 0.2 to $2.8 \%$ and 0.5 to 
$8.0 \%$, respectively) compared with kidney (range 0.16 to $0.38 \%)$ and liver recipients $(0.04 \%)$. The median onset is $\geq 1$ year post-transplantation, later than tuberculosis [114]. Chronic cough, sputum production and hemoptysis are common in lung infection, whereas disseminated disease (fever, night sweats, etc.) and cutaneous infection are rarer with MAC. Rapidly growing mycobacteria usually cause limited cutaneous disease; $M$. abscessus and $M$. chelonae may cause more severe and disseminated diseases [115]. NTM should be suspected in SOT recipients with pulmonary symptoms, particularly lung transplant recipients with chronic allograft dysfunction; all bronchoscopy specimens and all atypical skin lesions should be biopsied, stained and cultured for acid-fast bacilli. Radiology features overlap with many other entities and TB [114]. NTM-associated mortality is generally low, but large studies are scarce. Infections caused by M. abscessus have worse outcomes, particularly in lung transplant recipients, and pre-transplant colonization is considered a contra-indication to lung transplantation by some transplant centers. NTM infections in lung recipients are associated with increased mortality and poor allograft function despite control of the infection [116]. Treatment may be challenged by interactions of rifamycins and clarithromycin, both significant components of NTM treatment regimens, with the calcineurin inhibitors and rapamycin [114]. As mentioned above for fungal infections, lowering of the dose of immunosuppressants may trigger IRS with all mycobacterial infections [7].

Endemic fungi (Histoplasma capsulatum, Coccidioides spp., Paracoccidioides spp., Blastomyces dermatitidis, Cryptococcus gattii) can cause disease in geographically specified areas, whereas other pathogens common in the environment, such as Cryptococcus neoformans, Aspergillus spp. and Cryptosporidia spp., have worldwide distribution. Clinical features, severity and duration of infection may vary significantly compared with normal hosts or other groups of immunosuppressed hosts (i.e., HIV patients) [31, 117]. Lymphocytic choriomeningitis virus (LCMV), rabies virus, Leishmania spp., Trypanosoma cruzi (causing Chagas disease), Balamuthia mandrillaris, Encephalitozoon cuniculi (causing microsporidiosis), Strongyloides stercoralis, Echinococcus granulosus, Filariae spp., Schistosoma spp. and Plasmodium spp. can cause donor-derived infections [31, 117, 118]. Most of these infections can present with an aggravated or non-typical course because of immunosuppression, and mortality varies depending on the pathogen, depth of immunosuppression and rapidity of diagnosis. LCMV was transmitted to all organ transplant recipients causing death in seven of eight recipients from the same donor in one report [31]. Most of the above-mentioned pathogens cause geographically restricted infections; therefore, strict screening protocols have to be applied to the donor and/or the recipient, according to their anticipated local exposure to unusual pathogens [119].

\section{Conclusion}

Infection in SOT recipients is a frequent cause of admission in the ICU and is associated with both morbidity and mortality. Early diagnostic approaches are required to improve the prognosis. The diagnostic approaches should combine available knowledge on postoperative infections and profound immune suppression at the early phase, established immunocompromised status in the intermediate phase, and both community and opportunistic infections at the late phase. The empirical therapy should be decided early according to epidemiology, clinical presentation and emergent diagnostic procedures taking into account possible toxicity, pharmacokinetics and interactions with immunosuppressive therapy.

\section{Author details \\ ${ }^{1}$ Medical and Infectious Diseases ICU (MI2), APHP Bichat University Hospital, 75018 Paris, France. ${ }^{2}$ Inserm IAME U1137 IAME: Decision Sciences in Infec- tious Diseases (DeScID), University Paris, Diderot, 75018 Paris, France. ${ }^{3}$ Medical and Infectious Diseases Intensive Care Unit, AP-HP, Bichat-Claude Bernard University Hospital, Paris Diderot University, Paris, France. ${ }^{4}$ UMR1148, LVTS, Sorbonne Paris Cité, Inserm, Paris Diderot University, Paris, France. ${ }^{5}$ Trans- plant Infectious Diseases Program, University of Nebraska Medical Center, 98500 Nebraska Medical Center, Omaha, NE 68198, USA. ${ }^{6}$ Infectious Diseases Clinic, Department of Medicine, University of Udine and Azienda Sanitaria Universitaria Integrata, Udine, Italy. ${ }^{7}$ Department of Intensive Care, Shock, Organ Dysfunction and Resuscitation Research Group (SODIR-VHIR), Vall D'Hebron University Hospital, Barcelona, Spain. ${ }^{8}$ Anaesthesia and Criti- cal Care Department, Saint Eloi Teaching Hospital, PhyMedExp University of Montpellier, 34295 Montpellier, France. ${ }^{9}$ Service de Maladies Infectieuses et Tropicales, Hôpital Necker-Enfants Malades, Assistance Publique-Hôpitaux de Paris (APHP), Université Paris Descartes, Paris, France. ${ }^{10}$ Institut Pasteur, CNRS, Centre National de Référence Mycoses Invasives et Antifongiques, Unité de Mycologie Moléculaire, UMR 2000, Paris, France. ${ }^{11}$ Médecine Intensive Réanimation, Cardiology Institute, Pitié-Salpêtrière Hospital, Assistance Publique-Hôpitaux de Paris, Paris, France. ${ }^{12}$ UPMC Université Paris 06, INSERM, UMRS_1166-ICAN Institute of Cardiometabolism and Nutrition, Sorbonne Universités, Paris, France. ${ }^{13}$ Anesthesiology, Pain and Intensive Care Depart- ment, Federal University of São Paulo, São Paulo, Brazil. ${ }^{14}$ Division of Infectious Diseases, University of Genova (DISSAL) and Ospedale Polyclinico San Martino, Genova, Italy. ${ }^{15}$ Service de Médecine Intensive-Réanimation, Hôpital Nord- AP-HM, Aix-Marseille Université, Marseille, France. ${ }^{16}$ Service de Médecine Intensive-Réanimation, Hôpital Cochin, Hôpitaux Universitaires Paris-Centre, Assistance Publique-Hôpitaux de Paris, Paris, France. ${ }^{17}$ Institut Cochin, INSERM U1016-CNRS, UMR 8104, Université Paris Descartes, Paris, France. ${ }^{18}$ 3rd Depart- ment of Medicine, School of Medicine, Sotiria General Hospital of Athens, Athens National and Kapodistrian University, 152 Mesogion St, 11527 Athens, Greece. ${ }^{19}$ Service de Réanimation Neurochirurgicale, Hôpital Sainte-Anne, GHU Paris Psychiatrie \& Neurosciences, 1, Rue Cabanis, 75014 Paris, France. ${ }^{20}$ Medical ICU, Saint-Louis Hospital, AP-HP, INSERM U976, Paris Diderot Univer- sity, Paris, France. ${ }^{21}$ Transplant Infectious Diseases Unit, University Hospitals Geneva, Rue Gabrielle-Perret-Gentil 4, 1205 Geneva, Switzerland.}

\section{Compliance with ethical standards}

\section{Conflicts of interest}

MB has participated in advisory boards and/or received speaker honoraria from Achaogen, Angelini, Astellas, AstraZeneca, Bayer, Basilea, Biomerieux, Cidara, Gilead, Menarini, MSD, Nabriva, Paratek, Pfizer, Roche, The Medicine 
Company, Shionogi, Tetraphase, VenatoRx and Vifor. RF reports participation in scientific advisory boards: MSD, Shionogi and lectures: Beckton-Dickinson, MSD, Astelas, Pfizer, Thermo, Estor. SJ reports receiving consulting fees from Drager, Hamilton, Maquet, Medtronic and Fisher \& Paykel. CEL reports participations in advisory boards (Bayer Healthcare, Carmat, Faron, ThermoFischer Brahms) and lectures (MSD, Nihon-Koden, Biomérieux). MM has received payment for lectures, advisory board participation and travel expenses from MSD, Jansen, Pfizer, Astelas, Gilead, all outside the submitted work. FP reports lecture fees paid to his institution by ALEXION. JFT reports participation to scientific advisory boards (Astra-Zeneca, Pfizer, MSD, Nabriva, Gilead), lectures (Biomerieux, MSD, Astelas, 3M, Pfizer) and scientific grants (MSD, Pfizer). CV reports personal fees from MSD Int, Gilead, Pfizer, Angelini, Astelas and Basilea. LZ reports scientific grants not related to the review by Jazz Pharmaceuticals.

\section{Publisher's Note}

Springer Nature remains neutral with regard to jurisdictional claims in published maps and institutional affiliations.

\section{Received: 23 February 2019 Accepted: 6 March 2019} Published online: 25 March 2019

\section{References}

1. Lund LH, Khush KK, Cherikh WS, Goldfarb S, Kucheryavaya AY, Levvey BJ, Meiser B, Rossano JW, Chambers DC, Yusen RD, Stehlik J (2017) The registry of the international society for heart and lung transplantation: thirty-fourth adult heart transplantation report-2017; focus theme: allograft ischemic time. J Heart Lung Transplant Off Publ Int Soc Heart Transplant 36:1037-1046

2. Kalil AC, Levitsky J, Lyden E, Stoner J, Freifeld AG (2005) Meta-analysis: the efficacy of strategies to prevent organ disease by cytomegalovirus in solid organ transplant recipients. Ann Intern Med 143:870-880

3. Kalil AC, Dakroub H, Freifeld AG (2007) Sepsis and solid organ transplantation. Curr Drug Targets 8:533-541

4. Fishman JA, Rubin RH (1998) Infection in organ-transplant recipients. N Engl J Med 338:1741-1751

5. Fishman JA (2017) Infection in organ transplantation. Am J Transplant Off J Am Soc Transplant Am Soc Transpl Surg 17:856-879

6. Poole D, Skurzak S, Mehra MR (2018) Prediction of optimal outcomes in organ transplantation. Intensive Care Med. https://doi.org/10.1007/ s00134-018-5472-6

7. Pons S, Sonneville R, Bouadma L, Styfalova L, Ruckly S, Neuville M, Radjou A, Lebut J, Dilly MP, Mourvillier B, Dorent R, Nataf P, Wolff M, Timsit JF (2019) Infectious complications following heart transplantation in the era of high-priority allocation and extracorporeal membrane oxygenation. Ann Intensive Care 9:17

8. Hsu J, Griffith BP, Dowling RD, Kormos RL, Dummer JS, Armitage JM, Zenati M, Hardesty RL (1989) Infections in mortally ill cardiac transplant recipients. J Thorac Cardiovasc Surg 98:506-509

9. Valapour M, Lehr CJ, Skeans MA, Smith JM, Carrico R, Uccellini K, Lehman R, Robinson A, Israni AK, Snyder JJ, Kasiske BL (2018) OPTN/ SRTR 2016 annual data report: lung. Am J Transplant Off J Am Soc Transplant Am Soc Transpl Surg 18(Suppl 1):363-433

10. Zalawadiya S, Fudim M, Bhat G, Cotts W, Lindenfeld J (2017) Extracorporeal membrane oxygenation support and post-heart transplant outcomes among United States adults. J Heart Lung Transplant Off Publ Int Soc Heart Transplant 36:77-81

11. Dorschner P, McElroy LM, Ison MG (2014) Nosocomial infections within the first month of solid organ transplantation. Transpl Infect Dis Off J Transplant Soc 16:171-187

12. Green M (2013) Introduction: infections in solid organ transplantation. Am JTransplant 13(Suppl 4):3-8

13. Chuang P, Parikh CR, Langone A (2005) Urinary tract infections after renal transplantation: a retrospective review at two US transplant centers. Clin Transplant 19:230-235

14. Koivusalo A, Isoniemi H, Salmela K, Hockerstedt K (1994) Biliary complications in 100 adult liver transplantations: a retrospective clinical study. Transpl Int 7(Suppl 1):S119-S120
15. Kusne S, Dummer JS, Singh N, Iwatsuki S, Makowka L, Esquivel C, Tzakis AG, Starzl TE, Ho M (1988) Infections after liver transplantation. An analysis of 101 consecutive cases. Medicine (Baltimore) 67:132-143

16. Curry MP, Forns X, Chung RT, Terrault NA, Brown R Jr, Fenkel JM, Gordon F, O'Leary J, Kuo A, Schiano T, Everson G, Schiff E, Befeler A, Gane E, Saab S, McHutchison JG, Subramanian GM, Symonds WT, Denning J, McNair L, Arterburn S, Svarovskaia E, Moonka D, Afdhal N (2015) Sofosbuvir and ribavirin prevent recurrence of HCV infection after liver transplantation: an open-label study. Gastroenterology 148(100-107):e101

17. Levitsky J, Verna EC, O'Leary JG, Bzowej NH, Moonka DK, Hyland RH, Arterburn S, Dvory-Sobol H, Brainard DM, McHutchison JG, Terrault NA (2016) Perioperative ledipasvir-sofosbuvir for HCV in liver-transplant recipients. N Engl J Med 375:2106-2108

18. Myers TJ, Khan T, Frazier OH (2000) Infectious complications associated with ventricular assist systems. ASAIO J 46:S28-S36

19. De Vlaminck I, Martin L, Kertesz M, Patel K, Kowarsky M, Strehl C, Cohen G, Luikart H, Neff NF, Okamoto J, Nicolls MR, Cornfield D, Weill D, Valantine H, Khush KK, Quake SR (2015) Noninvasive monitoring of infection and rejection after lung transplantation. Proc Natl Acad Sci USA 112:13336-13341

20. Goldberg DS, Abt PL, Blumberg EA, Van Deerlin VM, Levine M, Reddy KR, Bloom RD, Nazarian SM, Sawinski D, Porrett P, Naji A, Hasz R, Suplee L, Trofe-Clark J, Sicilia A, McCauley M, Farooqi M, Gentile C, Smith J, Reese PP (2017) Trial of transplantation of HCV-infected kidneys into uninfected recipients. N Engl J Med 376:2394-2395

21. Ison MG, Hager J, Blumberg E, Burdick J, Carney K, Cutler J, Dimaio JM, Hasz R, Kuehnert MJ, Ortiz-Rios E, Teperman L, Nalesnik M (2009) Donorderived disease transmission events in the United States: data reviewed by the OPTN/UNOS Disease Transmission Advisory Committee. Am J Transplant 9:1929-1935

22. Mularoni A, Bertani A, Vizzini G, Gona F, Campanella M, Spada M, Gruttadauria S, Vitulo P, Conaldi P, Luca A, Gridelli B, Grossi P (2015) Outcome of transplantation using organs from donors infected or colonized with carbapenem-resistant gram-negative bacteria. Am J Transplant 15:2674-2682

23. Levesque E, Suet G, Merle JC, Compagnon P, Amathieu R, Feray C, Botterel F, Foulet F, Azoulay D, Dhonneur G (2014) Candida vascular complication in a liver transplant recipient due to yeast contamination of preservation solution. Transpl Infect Dis Off J Transplant Soc 16:827-829

24. Mittal C, Hassan S, Arshad S, Jeepalyam S, Bruni S, Miceli M, Jacobsen G, Abouljoud M, Bajjoka I, Ramesh M, Alangaden G (2014) Clostridium difficile infection in liver transplant recipients: a retrospective study of rates, risk factors and outcomes. Am J Transplant 14:1901-1907

25. Hsu RB, Chang Cl, Fang CT, Chang SC, Wang SS, Chu SH (2011) Bloodstream infection in heart transplant recipients: 12-year experience at a university hospital in Taiwan. Eur J Cardiothorac Surg 40:1362-1367

26. Wan Q, Ye Q, Zhou J (2013) Mortality predictors of bloodstream infections in solid-organ transplant recipients. Exp Clin Transplant 11:211-214

27. Florescu DF, Sandkovsky U, Kalil AC (2017) Sepsis and challenging infections in the immunosuppressed patient in the intensive care unit. Infect Dis Clin N Am 31:415-434

28. Trzeciak S, Sharer R, Piper D, Chan T, Kessler C, Dellinger RP, Pursell KJ (2004) Infections and severe sepsis in solid-organ transplant patients admitted from a university-based ED. Am J Emerg Med 22:530-533

29. Kalil AC, Syed A, Rupp ME, Chambers H, Vargas L, Maskin A, Miles CD, Langnas A, Florescu DF (2015) Is bacteremic sepsis associated with higher mortality in transplant recipients than in nontransplant patients? A matched case-control propensity-adjusted study. Clin Infect Dis Off Publ Infect Dis Soc Am 60:216-222

30. Bodro M, Sabe N, Tubau F, Llado L, Baliellas C, Roca J, Cruzado JM, Carratala J (2013) Risk factors and outcomes of bacteremia caused by drug-resistant ESKAPE pathogens in solid-organ transplant recipients. Transplantation 96:843-849

31. Canet E, Zafrani L, Azoulay E (2016) The critically ill kidney transplant recipient: a narrative review. Chest 149:1546-1555

32. Azoulay E, Pickkers P, Soares M, Perner A, Rello J, Bauer PR, van de Louw A, Hemelaar P, Lemiale V, Taccone FS, Martin Loeches I, MeyhoffTS, Salluh J, Schellongowski P, Rusinova K, Terzi N, Mehta S, Antonelli M, Kouatchet A, Barratt-Due A, Valkonen M, Landburg PP, Bruneel F, Bukan RB, Pene F, Metaxa V, Moreau AS, Souppart V, Burghi G, Girault C, Silva 
UVA, Montini L, Barbier F, Nielsen LB, Gaborit B, Mokart D, Chevret S (2017) Acute hypoxemic respiratory failure in immunocompromised patients: the Efraim multinational prospective cohort study. Intensive Care Med 43:1808-1819

33. Kotloff RM, Ahya VN, Crawford SW (2004) Pulmonary complications of solid organ and hematopoietic stem cell transplantation. Am J Respir Crit Care Med 170:22-48

34. Zeyneloglu P (2015) Respiratory complications after solid-organ transplantation. Exp Clin Transplant 13:115-125

35. Fernandez-Ruiz M, Lopez-Medrano F, Romo EM, Allende LM, Meneu JC, Fundora-Suarez Y, San-Juan R, Lizasoain M, Paz-Artal E, Aguado JM (2009) Pretransplant lymphocyte count predicts the incidence of infection during the first two years after liver transplantation. Liver Transpl 15:1209-1216

36. Nierenberg NE, Poutsiaka DD, Chow JK, Cooper J, Price LL, Freeman RB, Rohrer R, Snydman DR (2014) Pretransplant lymphopenia is a novel prognostic factor in cytomegalovirus and noncytomegalovirus invasive infections after liver transplantation. Liver Transpl 20:1497-1507

37. Sarmiento E, Navarro J, Fernandez-Yanez J, Palomo J, Munoz P, Carbone $J(2014)$ Evaluation of an immunological score to assess the risk of severe infection in heart recipients. Transpl Infect Dis 16:802-812

38. Calarota SA, Zelini P, De Silvestri A, Chiesa A, Comolli G, Sarchi E, Migotto C, Pellegrini C, Esposito P, Minoli L, Tinelli C, Marone P, Baldanti F (2012) Kinetics of T-lymphocyte subsets and posttransplant opportunistic infections in heart and kidney transplant recipients. Transplantation 93:112-119

39. Fernandez-Ruiz M, Lopez-Medrano F, Allende LM, Andres A, GarciaReyne A, Lumbreras C, San-Juan R, Morales JM, Paz-Artal E, Aguado JM (2014) Kinetics of peripheral blood lymphocyte subpopulations predicts the occurrence of opportunistic infection after kidney transplantation. Transpl Int 27:674-685

40. Ling X, Xiong J, Liang W, Schroder PM, Wu L, Ju W, Kong Y, Shang Y, Guo Z, He X (2012) Can immune cell function assay identify patients at risk of infection or rejection? A meta-analysis. Transplantation 93:737-743

41. Mian M, Natori Y, Ferreira V, Selzner N, Husain S, Singer L, Kim SJ, Humar A, Kumar D (2018) Evaluation of a novel global immunity assay to predict infection in organ transplant recipients. Clin Infect Dis 66:1392-1397

42. Aguado JM, Silva JT, Fernandez-Ruiz M, Cordero E, Fortun J, Gudiol C, Martinez-Martinez L, Vidal E, Almenar L, Almirante B, Canton R, Carratala J, Caston JJ, Cercenado E, Cervera C, Cisneros JM, Crespo-Leiro MG, Cuervas-Mons V, Elizalde-Fernandez J, Farinas MC, Gavalda J, Goyanes MJ, Gutierrez-Gutierrez B, Hernandez D, Len O, Lopez-Andujar R, LopezMedrano F, Martin-Davila P, Montejo M, Moreno A, Oliver A, Pascual A, Perez-Nadales E, Roman-Broto A, San-Juan R, Seron D, Sole-Jover A, Valerio M, Munoz P, Torre-Cisneros J, Spanish Society of T, Group for Study of Infection in Transplantation of the Spanish Society of Infectious D, Clinical M, Spanish Network for Research in Infectious D (2018) Management of multidrug resistant gram-negative bacilli infections in solid organ transplant recipients: SET/GESITRA-SEIMC/REIPI recommendations. Transplant Rev (Orlando) 32:36-57

43. van Duin D, van Delden C, Practice ASTIDCo (2013) Multidrug-resistant gram-negative bacteria infections in solid organ transplantation. Am J Transplant 13(Suppl 4):31-41

44. Garrido RS, Aguado JM, Diaz-Pedroche C, Len O, Montejo M, Moreno A, Gurgui M, Torre-Cisneros J, Pareja F, Segovia J, Garcia M, Lumbreras C (2006) A review of critical periods for opportunistic infection in the new transplantation era. Transplantation 82:1457-1462

45. Helfrich M, Dorschner P, Thomas K, Stosor V, Ison MG (2017) A retrospective study to describe the epidemiology and outcomes of opportunistic infections after abdominal organ transplantation. Transpl Infect Dis. https://doi.org/10.1111/tid.12691

46. Kotton CN, Kumar D, Caliendo AM, Huprikar S, Chou S, Danziger-Isakov L, Humar A, The Transplantation Society International CMVCG (2018) The third international consensus guidelines on the management of cytomegalovirus in solid-organ transplantation. Transplantation 102:900-931

47. Florescu DF, Kalil AC, Qiu F, Grant W, Morris MC, Schmidt CM, Florescu MC, Poole JA (2014) Does increasing immunoglobulin levels impact survival in solid organ transplant recipients with hypogammaglobulinemia? Clin Transplant 28:1249-1255
48. Florescu DF, Kalil AC, Qiu F, Schmidt CM, Sandkovsky U (2013) What is the impact of hypogammaglobulinemia on the rate of infections and survival in solid organ transplantation? A meta-analysis. Am J Transplant Off J Am Soc Transplant Am Soc Transpl Surg 13:2601-2610

49. Fishman JA (2014) From the classic concepts to modern practice. Clin Microbiol Infect 20(Suppl 7):4-9

50. Kupeli E, Eyuboglu FO, Haberal M (2012) Pulmonary infections in transplant recipients. Curr Opin Pulm Med 18:202-212

51. De Gasperi A, Feltracco P, Ceravola E, Mazza E (2014) Pulmonary complications in patients receiving a solid-organ transplant. Curr Opin Crit Care 20:411-419

52. Lichtenstein DA, Meziere GA (2008) Relevance of lung ultrasound in the diagnosis of acute respiratory failure: the BLUE protocol. Chest 134:117-125

53. Weiss E, Paugam-Burtz C, Jaber S (2018) Shock etiologies and fluid management in liver failure. Semin Respir Crit care Med 39:538-545

54. Bailly S, Leroy O, Montravers P, Constantin JM, Dupont H, Guillemot D, Lortholary O, Mira JP, Perrigault PF, Gangneux JP, Azoulay E, Timsit JF (2015) Antifungal de-escalation was not associated with adverse outcome in critically ill patients treated for invasive candidiasis: post hoc analyses of the AmarCAND2 study data. Intensive Care Med 41:1931-1940

55. Benoit DD, Doig G, Timsit JF (2016) Focus on adequate antimicrobial treatment and de-escalation in the ICU. Intensive Care Med 42:1856-1858

56. Jung B, Cisse M, Chanques G, Arsac E, Bismuth M, Panaro F, Perrigault PF, Souche B, Gallix B, Verzilli D, Delay JM, Navarro F, Pageaux GP, Jaber S (2011) Causes of early mortality after liver transplantation: a twentyyears single centre experience. Ann Fr Anesth Reanim 30:899-904

57. Kalil AC, Opal SM (2015) Sepsis in the severely immunocompromised patient. Curr Infect Dis Rep 17:487

58. Schachtner T, Stein M, Reinke P (2017) Sepsis after renal transplantation: clinical, immunological, and microbiological risk factors. Transpl Infect Dis Off J Transplant Soc. https://doi.org/10.1111/tid.12695

59. Trofe-Clark J, Lemonovich TL (2013) Interactions between anti-infective agents and immunosuppressants in solid organ transplantation. Am J Transplant Off J Am Soc Transplant Am Soc Transpl Surg 13(Suppl 4):318-326

60. Hamandi B, Holbrook AM, Humar A, Brunton J, Papadimitropoulos EA, Wong GG, Thabane L (2009) Delay of adequate empiric antibiotic therapy is associated with increased mortality among solid-organ transplant patients. Am J Transplant Off J Am Soc Transplant Am Soc Transpl Surg 9:1657-1665

61. de Carvalho MA, Freitas FG, Silva Junior HT, Bafi AT, Machado FR, Pestana JO (2014) Mortality predictors in renal transplant recipients with severe sepsis and septic shock. PLoS ONE 9:e111610

62. Hotchkiss RS, Moldawer LL, Opal SM, Reinhart K, Turnbull IR, Vincent IL (2016) Sepsis and septic shock. Nat Rev Dis Prim 2:16045

63. Tu GW, Ju MJ, Zheng YJ, Zhu DM, Xu M, Rong RM, Zhu TY, Luo Z (2014) An interdisciplinary approach for renal transplant recipients with severe pneumonia: a single ICU experience. Intensive care Med 40:914-915

64. Bige N, Zafrani L, Lambert J, Peraldi MN, Snanoudj R, Reuter D, Legendre C, Chevret S, Lemiale V, Schlemmer B, Azoulay E, Canet E (2014) Severe infections requiring intensive care unit admission in kidney transplant recipients: impact on graft outcome. Transpl Infect Dis Off J Transplant Soc 16:588-596

65. Annane D, Renault A, Brun-Buisson C, Megarbane B, Quenot JP, Siami S, Cariou A, Forceville X, Schwebel C, Martin C, Timsit JF, Misset B, Ali Benali M, Colin G, Souweine B, Asehnoune K, Mercier E, Chimot L, Charpentier C, Francois B, Boulain T, Petitpas F, Constantin JM, Dhonneur G, Baudin F, Combes A, Bohe J, Loriferne JF, Amathieu R, Cook F, Slama M, Leroy O, Capellier G, Dargent A, Hissem T, Maxime V, Bellissant E (2018) Hydrocortisone plus fludrocortisone for adults with septic shock. New Engl J Med 378:809-818

66. Patel MS, Niemann CU, Sally MB, De La Cruz S, Zatarain J, Ewing T, Crutchfield M, Enestvedt CK, Malinoski DJ (2015) The impact of hydroxyethyl starch use in deceased organ donors on the development of delayed graft function in kidney transplant recipients: a propensityadjusted analysis. Am J Transplant Off J Am Soc Transplant Am Soc Transpl Surg 15:2152-2158 
67. Rhodes A, Evans LE, Alhazzani W, Levy MM, Antonelli M, Ferrer R, Kumar A, Sevransky JE, Sprung CL, Nunnally ME, Rochwerg B, Rubenfeld GD, Angus DC, Annane D, Beale RJ, Bellinghan GJ, Bernard GR, Chiche JD, Coopersmith C, De Backer DP, French CJ, Fujishima S, Gerlach H, Hidalgo JL, Hollenberg SM, Jones AE, Karnad DR, Kleinpell RM, Koh Y, Lisboa TC, Machado FR, Marini JJ, Marshall JC, Mazuski JE, Mclntyre LA, McLean AS, Mehta S, Moreno RP, Myburgh J, Navalesi P, Nishida O, Osborn TM, Perner A, Plunkett CM, Ranieri M, Schorr CA, Seckel MA, Seymour CW, Shieh L, Shukri KA, Simpson SQ, Singer M, Thompson BT, Townsend SR, Van der Poll T, Vincent JL, Wiersinga WJ, Zimmerman JL, Dellinger RP (2017) Surviving sepsis campaign: international guidelines for management of sepsis and septic shock: 2016. Intensive Care Med 43:304-377

68. Bafi AT, Tomotani DY, de Freitas FG (2017) Sepsis in solid-organ transplant patients. Shock 47:12-16

69. Wright AJ, Fishman JA (2014) Central nervous system syndromes in solid organ transplant recipients. Clin Infect Dis Off Publ Infect Dis Soc Am 59:1001-1011

70. Sonneville R, Magalhaes E, Meyfroidt G (2017) Central nervous system infections in immunocompromised patients. Curr Opin Crit Care 23:128-133

71. Sonneville R, Mariotte E, Brouwer MC (2019) Cerebral complications of solid organ transplantation. Intensive Care Med. https://doi. org/10.1007/s00134-019-05540-1

72. McCarthy M, Rosengart A, Schuetz AN, Kontoyiannis DP, Walsh TJ (2014) Mold infections of the central nervous system. New Engl J Med 371:150-160

73. Brouwer MC, Tunkel AR, van de Beek D (2014) Brain abscess. New Engl J Med 371:1758

74. Marzolf G, Sabou M, Lannes B, Cotton F, Meyronet D, Galanaud D, Cottier JP, Grand S, Desal H, Kreutz J, Schenck M, Meyer N, Schneider F, Dietemann JL, Koob M, Herbrecht R, Kremer S (2016) Magnetic resonance imaging of cerebral aspergillosis: imaging and pathological correlations. PLOS ONE 11:e0152475

75. Coussement J, Lebeaux D, van Delden C, Guillot H, Freund R, Marbus S, Melica G, Van Wijngaerden E, Douvry B, Van Laecke S, Vuotto F, Tricot L, Fernandez-Ruiz M, Dantal J, Hirzel C, Jais JP, Rodriguez-Nava V, Lortholary O, Jacobs F (2016) Nocardia infection in solid organ transplant recipients: a multicenter European case-control study. Clin Infect Dis Off Publ Infect Dis Soc Am 63:338-345

76. Coussement J, Lebeaux D, Rouzaud C, Lortholary O (2017) Nocardia infections in solid organ and hematopoietic stem cell transplant recipients. Current Opin Infect Dis 30:545-551

77. Schmidt M, Sonneville R, Schnell D, Bige N, Hamidfar R, Mongardon N, Castelain V, Razazi K, Marty A, Vincent F, Dres M, Gaudry S, Luyt CE, Das V, Micol JB, Demoule A, Mayaux J (2013) Clinical features and outcomes in patients with disseminated toxoplasmosis admitted to intensive care: a multicenter study. Clinl Infect Dis Off Publ Infect Dis Soc Am 57:1535-1541

78. Fernandez-Sabe N, Cervera C, Farinas MC, Bodro M, Munoz P, Gurgui M, Torre-Cisneros J, Martin-Davila P, Noblejas A, Len O, Garcia-Reyne A, Del Pozo JL, Carratala J (2012) Risk factors, clinical features, and outcomes of toxoplasmosis in solid-organ transplant recipients: a matched casecontrol study. Clin Infect Dis Off Publ Infect Dis Soc Am 54:355-361

79. van Veen KE, Brouwer MC, van der Ende A, van de Beek D (2016) Bacterial meningitis in solid organ transplant recipients: a population-based prospective study. Transpl Infect Dis Off J Transplant Soc 18:674-680

80. George IA, Santos CAQ, Olsen MA, Powderly WG (2017) Epidemiology of cryptococcosis and cryptococcal meningitis in a large retrospective cohort of patients after solid organ transplantation. Open Forum Infect Dis 4:ofx004

81. Cantier M, Morisot A, Guerot E, Megarbane B, Razazi K, Contou D, Mariotte E, Canet E, De Montmollin E, Dubee V, Boulet E, Gaudry S, Voiriot G, Mayaux J, Pene F, Neuville M, Mourvillier B, Ruckly S, Bouadma L, Wolff M, Timsit JF, Sonneville R (2018) Functional outcomes in adults with tuberculous meningitis admitted to the ICU: a multicenter cohort study. Crit Care 22:210

82. Saylor D, Thakur K, Venkatesan A (2015) Acute encephalitis in the immunocompromised individual. Curr Opin Infect Dis 28:330-336
83. Mateen FJ, Muralidharan R, Carone M, van de Beek D, Harrison DM, Aksamit AJ, Gould MS, Clifford DB, Nath A (2011) Progressive multifocal leukoencephalopathy in transplant recipients. Ann Neurol 70:305-322

84. Silva JT, Fernandez-Ruiz M, Aguado JM (2018) Multidrug-resistant gramnegative infection in solid organ transplant recipients: implications for outcome and treatment. Curr Opin Infect Dis 31:499-505

85. Qiao B, Wu J, Wan Q, Zhang S, Ye Q (2017) Factors influencing mortality in abdominal solid organ transplant recipients with multidrug-resistant gram-negative bacteremia. BMC Infect Dis 17:171

86. Timsit JF, Bassetti M, Cremer O, Daikos G, de Waele J, Kallil A, Kipnis E, Kollef M, Laupland K, Paiva JA, Rodriguez-Bano J, Ruppe E, Salluh J, Taccone FS, Weiss E, Barbier F (2019) Rationalizing antimicrobial therapy in the ICU: a narrative review. Intensive Care Med 45:172-189

87. Camargo LF, Marra AR, Pignatari AC, SukiennikT, Behar PP, Medeiros EA, Ribeiro J, Girao E, Correa L, Guerra C, Brites C, Pereira CA, Carneiro I, Reis M, Souza MA, Barata CU, Edmond MB (2015) Nosocomial bloodstream infections in a nationwide study: comparison between solid organ transplant patients and the general population. Transpl Infect Dis Off J Transplant Soc 17:308-313

88. Kritikos A, Manuel O (2016) Bloodstream infections after solid-organ transplantation. Virulence 7:329-340

89. Cervera C, van Delden C, Gavalda J, Welte T, Akova M, Carratala J (2014) Multidrug-resistant bacteria in solid organ transplant recipients. Clin Microbiol Infect Off Publ Eur Soc Clin Microbiol Infect Diss 20(Suppl 7):49-73

90. Neofytos D, Fishman JA, Horn D, Anaissie E, Chang CH, Olyaei A, Pfaller M, Steinbach WJ, Webster KM, Marr KA (2010) Epidemiology and outcome of invasive fungal infections in solid organ transplant recipients. Transpl Infect Dis Off J Transplant Soc 12:220-229

91. Husain S, Silveira FP, Azie N, Franks B, Horn D (2017) Epidemiological features of invasive mold infections among solid organ transplant recipients: PATH Alliance (R) registry analysis. Med Mycol 55:269-277

92. Albano L, Bretagne S, Mamzer-Bruneel MF, Kacso I, Desnos-Ollivier M, Guerrini P, Le Luong T, Cassuto E, Dromer F, Lortholary O (2009) Evidence that graft-site candidiasis after kidney transplantation is acquired during organ recovery: a multicenter study in France. Clin Infect Dis Off Publ Infect Dis Soc Am 48:194-202

93. Camargo JF (2017) Donor-derived infections in solid organ transplant recipients: challenging the 30-day paradigm. Transpl Infect Disease Off J Transplant Soc. https://doi.org/10.1111/tid.12665

94. Kusne S, Taranto S, Covington S, Kaul DR, Blumberg EA, Wolfe C, Green M (2016) Coccidioidomycosis transmission through organ transplantation: a report of the OPTN ad hoc disease transmission advisory committee. Am J Transplant Off J Am Soc Transplant Am Soc Transplant Surg 16:3562-3567

95. Singh N, Perfect JR (2007) Immune reconstitution syndrome associated with opportunistic mycoses. Lancet Infect Dis 7:395-401

96. Sun HY, Alexander BD, Huprikar S, Forrest GN, Bruno D, Lyon GM, Wray D, Johnson LB, Sifri CD, Razonable RR, Morris MI, Stosor V, Wagener MM, Singh N (2015) Predictors of immune reconstitution syndrome in organ transplant recipients with cryptococcosis: implications for the management of immunosuppression. Clin Infect Dis Off Publ Infect Dis Soc Am 60:36-44

97. Scemla A, Gerber S, Duquesne A, Parize P, Martinez F, Anglicheau D, Snanoudj R, Zuber M, Bougnoux ME, Legendre C, Lortholary O (2015) Dramatic improvement of severe cryptococcosis-induced immune reconstitution syndrome with adalimumab in a renal transplant recipient. Am J Transplant Off J Am Soc Transplant Am Soc Transpl Surg 15:560-564

98. Andes DR, Safdar N, Baddley JW, Alexander B, Brumble L, Freifeld A, Hadley S, Herwaldt L, Kauffman C, Lyon GM, Morrison V, Patterson T, Perl T, Walker R, Hess T, Chiller T, Pappas PG (2016) The epidemiology and outcomes of invasive Candida infections among organ transplant recipients in the United States: results of the Transplant-Associated Infection Surveillance Network (TRANSNET). Transpl Infect Dis Off J Transplant Soc 18:921-931

99. Mutschlechner W, Risslegger B, Willinger B, Hoenigl M, Bucher B, Eschertzhuber S, Lass-Florl C (2015) Bronchoalveolar lavage fluid $(1,3)$ beta-d-glucan for the diagnosis of invasive fungal infections in solid organ transplantation: a prospective multicenter study. Transplantation 99:e140-e144 
100. Lopez-Medrano F, Fernandez-Ruiz M, Silva JT, Carver PL, van Delden C, Merino E, Perez-Saez MJ, Montero M, Coussement J, de Abreu Mazzolin M, Cervera C, Santos L, Sabe N, Scemla A, Cordero E, Cruzado-Vega L, Martin-Moreno PL, Len O, Rudas E, de Leon AP, Arriola M, Lauzurica R, David M, Gonzalez-Rico C, Henriquez-Palop F, Fortun J, Nucci M, Manuel O, Pano-Pardo JR, Montejo M, Munoz P, Sanchez-Sobrino B, Mazuecos A, Pascual J, Horcajada JP, Lecompte T, Moreno A, Carratala J, Blanes M, Hernandez D, Farinas MC, Andres A, Aguado JM (2016) Clinical presentation and determinants of mortality of invasive pulmonary aspergillosis in kidney transplant recipients: a multinational cohort study. Am J Transplant Off J Am Soc Transplant Am Soc Transpl Surg 16:3220-3234

101. Barchiesi F, Mazzocato S, Mazzanti S, Gesuita R, Skrami E, Fiorentini A, Singh N (2015) Invasive aspergillosis in liver transplant recipients: epidemiology, clinical characteristics, treatment, and outcomes in 116 cases. Liver Transplant Off Publ Am Assoc Study Liver Dis Int Liver Transplant Soc 21:204-212

102. Iriart X, Challan Belval T, Fillaux J, Esposito L, Lavergne RA, CardeauDesangles I, Roques O, Del Bello A, Cointault O, Lavayssiere L, Chauvin P, Menard S, Magnaval JF, Cassaing S, Rostaing L, Kamar N, Berry A (2015) Risk factors of pneumocystis pneumonia in solid organ recipients in the era of the common use of posttransplantation prophylaxis. Am J Transplant Off J Am Soc Transplant Am Soc Transpl Surg 15:190-199

103. Werbel WA, Ison MG, Angarone MP, Yang A, Stosor V (2018) Lymphopenia is associated with late onset Pneumocystis jirovecii pneumonia in solid organ transplantation. Transpl Infect Dis Off J Transplant Soc 20:e12876

104. Neofytos D, Hirzel C, Boely E, Lecompte T, Khanna N, Mueller NJ, Boggian K, Cusini A, Manuel O, van Delden C (2018) Pneumocystis jirovecii pneumonia in solid organ transplant recipients: a descriptive analysis for the Swiss Transplant Cohort. Transpl Infect Dis Off J Transplant Soc 20:e12984

105. Hodson EM, Jones CA, Webster AC, Strippoli GF, Barclay PG, Kable K, Vimalachandra D, Craig JC (2005) Antiviral medications to prevent cytomegalovirus disease and early death in recipients of solid-organ transplants: a systematic review of randomised controlled trials. Lancet 365:2105-2115

106. Martin-Loeches I, Schultz MJ, Vincent JL, Alvarez-Lerma F, Bos LD, Sole-Violan J, Torres A, Rodriguez A (2017) Increased incidence of co-infection in critically ill patients with influenza. Intensive Care Med 43:48-58

107. Kumar D, Ferreira VH, Blumberg E, Silveira F, Cordero E, Perez-Romero P, Aydillo T, Danziger-Isakov L, Limaye AP, Carratala J, Munoz P, Montejo M, Lopez-Medrano F, Farinas MC, Gavalda J, Moreno A, Levi M, Fortun J, Torre-Cisneros J, Englund JA, Natori Y, Husain S, Reid G, Sharma TS, Humar A (2018) A 5-year prospective multicenter evaluation of influenza infection in transplant recipients. Clin Infect Dis Off Publ Infect Dis Soc Am 67:1322-1329

108. Natori Y, Shiotsuka M, Slomovic J, Hoschler K, Ferreira V, Ashton P, Rotstein C, Lilly L, Schiff J, Singer L, Humar A, Kumar D (2018) A double-blind, randomized trial of high-dose vs standard-dose influenza vaccine in adult solid-organ transplant recipients. Clin Infect Dis Off Publ Infect Dis Soc Am 66:1698-1704

109. Cordero E, Roca-Oporto C, Bulnes-Ramos A, Aydillo T, Gavalda J, Moreno A, Torre-Cisneros J, Montejo JM, Fortun J, Munoz P, Sabe N, Farinas MC, Blanes-Julia M, Lopez-Medrano F, Suarez-Benjumea A, Martinez-Atienza J, Rosso-Fernandez C, Perez-Romero P (2017) Two doses of inactivated influenza vaccine improve immune response in solid organ transplant recipients: results of TRANSGRIPE 1-2, a randomized controlled clinical trial. Clin Infect Dis Off Publ Infect Dis Soc Am 64:829-838

110. Paulsen GC, Danziger-Isakov L (2017) Respiratory viral infections in solid organ and hematopoietic stem cell transplantation. Clin Chest Med 38:707-726

111. Grim SA, Reid GE, Clark NM (2017) Update in the treatment of noninfluenza respiratory virus infection in solid organ transplant recipients. Expt Opin Pharmacother 18:767-779

112. Peghin M, Los-Arcos I, Hirsch HH, Codina G, Monforte V, Bravo C, Berastegui C, Jauregui A, Romero L, Cabral E, Ferrer R, Sacanell J, Roman A, Len O, Gavalda J (2018) Community-acquired respiratory viruses are a risk factor for chronic lung allograft dysfunction. Clin Infect Dis Off Publ Infect Dis Soc Am

113. Kalil AC, Sandkovsky U, Florescu DF (2018) Severe infections in critically ill solid organ transplant recipients. Clin Microbiol Infect Off Publ Eur Soc Clin Microbiol Infect Dis 24:1257-1263

114. Keating MR, Daly JS (2013) Nontuberculous mycobacterial infections in solid organ transplantation. Am J Transplant Off J Am Soc Transplant Am Soc Transpl Surg 13(Suppl 4):77-82

115. Osmani M, Sotello D, Alvarez S, Odell JA, Thomas M (2018) Mycobacterium abscessus infections in lung transplant recipients: 15-year experience from a single institution. Transpl Infect Dis Off J Transplant Soc 20(2):e12835

116. Huang HC, Weigt SS, Derhovanessian A, Palchevskiy V, Ardehali A, Saggar R, Kubak B, Gregson A, Ross DJ, Lynch JP 3rd, Elashoff R, Belperio JA (2011) Non-tuberculous mycobacterium infection after lung transplantation is associated with increased mortality. J Heart Lung Transplant Off Publ Int Soc Heart Transplant 30:790-798

117. Saliba F, Delvart V, Ichai P, Kassis N, Botterel F, Mihaila L, Azoulay D, Adam R, Castaing D, Bretagne S, Samuel D (2013) Fungal infections after liver transplantation: outcomes and risk factors revisited in the MELD era. Clin Transplant 27:E454-E461

118. Len O, Garzoni C, Lumbreras C, Molina I, Meije Y, Pahissa A, Grossi P (2014) Recommendations for screening of donor and recipient prior to solid organ transplantation and to minimize transmission of donorderived infections. Clin Microbiol Infect Off Publ Eur Soc Clin Microbiol Infect Dis 20(Suppl 7):10-18

119. Fishman JA, Greenwald MA, Grossi PA (2012) Transmission of infection with human allografts: essential considerations in donor screening. Clin Infect Dis Off Publ Infect Dis Soc Am 55:720-727 